\title{
Meister Eckhart Reading Ibn Gabirol's Fons vitae
}

\section{Introduction}

The High Scholastic German Dominican Meister Eckhart (1260-1328) is renowned for his innovative philosophy that dared to break the mould of the accepted Scholastic worldview of his days. ${ }^{2}$ Some of the heterodox elements of his thought also seem to have originated from his favourable view of Jewish philosophical sources. The celebrated Jewish philosopher Maimonides (1135/38-1204) immediately comes to mind since his Judaeo-Arabic Aristotelianism exerted a formative impact on Eckhart. ${ }^{3}$ However, Maimonides is not the only Jewish philosopher to have shaped Eckhart's body of thought. A further philosophical source requiring scholarly attention is Fons vitae by the eleventh-century Jewish Andalusian Solomon Ibn Gabirol (1020/21-58), generally denoted in Scholasticism as Avicebron or as Avencebrol. Eckhart, who was not aware of Avicebron's Jewish faith, approvingly invokes his philosophical authority on several occasions. His treatment of Fons vitae's metaphysical assertions represents a constructive way of approaching Gabirolean thought which deviates from his Dominican predecessors, the ardent Aristotelians Albertus Magnus (c. 120080) and Thomas Aquinas (1225-74). These two thirteenth-century Scholastics are rather notorious for their critical attitude towards Avicebronian hylomorphism. ${ }^{4}$

\footnotetext{
1 The title of my article alludes to Yossef Schwartz's “To Thee Is Silence Praise": Meister Eckhart's Reading in Maimonides' Guide of the Perplexed [Hebrew] (Tel Aviv: Am Oved Publishers, 2002), in which he methodically reveals Meister Eckhart's dependency upon Maimonides, showing that he regarded "Rabbi Moyses" as a philosophical authority of the highest order.

2 See Kurt Flasch, Meister Eckhart: Philosopher of Christianity, trans. Anne Schindel and Aaron Vanides (New Haven: Yale University Press, 2015), 234-73.

3 For a further article by Schwartz on this subject matter, see Yossef Schwartz, "Meister Eckhart and Moses Maimonides: From Judaeo-Arabic Rationalism to Christian Mysticism," in A Companion to Meister Eckhart, ed. Jeremiah M. Hackett (Leiden: Brill, 2013), 389-414.

4 Cf. Alessandro Palazzo, "Eckhart's Islamic and Jewish Sources: Avicenna, Avicebron, and Averroes," in A Companion to Meister Eckhart, ed. Jeremiah M. Hackett (Leiden: Brill, 2013), 274; Fernand Brunner, "Maître Eckhart et Avicébron," in Lectionum Varietates. Hommage à Paul Vignaux (19041987), ed. Jean Jolivet, Zenon Kaluza, and Alain de Libera (Paris: Vrin, 1991), 150; Bernard McGinn, "Ibn Gabirol: The Sage among the Schoolmen," in Neoplatonism and Jewish Thought, ed. Lenn E. Goodman (Albany, NY: SUNY Press, 1992), 96-97. As Alessandro Palazzo correctly notes, despite Eckhart's positive approach to Ibn Gabirol, his treatment of his system of thought is still not on the same level of complexity and of similar elaboration as those of his fellow Dominicans: Palazzo, "Eckhart's Islamic and Jewish Sources,” 274.
} 
In this study, I set out to provide a brief overview of Eckhart's explicit and implicit references to Avicebron's Fons vitae. The main argument I will put forward is that Avicebron's metaphysics influenced Eckhart's Christian philosophy at significant points. I will aim to uncover this extensive usage and appropriation by bringing six central themes of Gabirolean thought to the fore: (1) divine creation; (2) the ultimate epistemological goal of the human soul; (3) emanation and its fourfold ordo essendi; (4) negative theology; (5) God's absolute transcendence and pure unity; and (6) universal hylomorphism. Our approach will not confine itself solely to Eckhart's explicit references to Fons vitae, but will also have recourse to implicit ones, especially when they appear to echo ideas present in the former. I wish to argue that Eckhart does not affirm particular thought patterns from Fons vitae while dismissing others. Rather, he appears to wholeheartedly endorse doctrines that are central to Avicebronian philosophy. Furthermore, I will attempt to establish that Eckhart was intimately familiar with Fons vitae, aptly evaluating it as advancing a metaphysics of the One.

I will show that through Ibn Gabirol's philosophy, Eckhart not only explicates the philosophical meaning of key verses from the Pentateuch, such as Gen 1:1, but also that of verses from the New Testament, a prime example being the prologue to the Gospel of John. In fact, contrary to his use of Maimonides, which is almost entirely limited to his exegesis of Jewish Scripture, ${ }^{5}$ Eckhart mainly invokes Avicebron in his reading of the New Testament. Nearly half of his mentions of Fons vitae are found in his Commentary on the Gospel of John. ${ }^{6}$ It is also noteworthy that seven out of Eckhart's overall twelve allusions to Ibn Gabirol refer specifically to topics found in the fifth chapter of Fons vitae. This particular chapter seems to bear the strongest resemblance to Christian theology, denoting, for example, God's Will (voluntas) in terms of the all-pervading divine Word (verbum) in section $36 .{ }^{7}$ By emphasising these points throughout this survey, I will prompt the conclusion that Eckhart assumed Avicebron to be a Christian thinker, through whom he can philosophically

5 See Bernard McGinn, The Mystical Thought of Meister Eckhart: The Man from Whom God Hid Nothing (New York: Crossroad, 2001), 271 n. 47.

6 See Palazzo, "Eckhart's Islamic and Jewish Sources," 275.

7 The writings of Ibn Gabirol will be cited in brackets according to Baeumker's critical edition: Avencebrolis (Ibn Gabirol) Fons Vitae, ex Arabico in Latinum Translatus ab Johanne Hispano et Dominico Gundissalino, ed. Clemens Baeumker, in Beiträge zur Geschichte der Philosophie des Mittelalters, Texte und Untersuchungen, vol. 1.2, ed. Clemens Baeumker and Georg von Hertling, 2nd ed. (Münster: Aschendorff, 1995), 323.17 (5:36) (henceforth FV). For the possible influence of the Longer Theology of Aristotle on Ibn Gabirol's theory of the divine Will, see Jacques Schlanger, The Philosophy of Solomon Ibn Gabirol [Hebrew] (Jerusalem: Magnes Press, 1980), 65-66; Sarah Pessin, "Solomon Ibn Gabirol [Avicebron]," in The Stanford Encyclopedia of Philosophy (Winter 2016 Edition), ed. Edward N. Zalta, https://plato.stanford.edu/archives/win2016/entries/ibn-gabirol/ (under section 4.2: "Will, Wisdom, Word, Intellect and the Cosmos”); Pessin, Ibn Gabirol's Theology of Desire: Matter and Method in Jewish Medieval Neoplatonism (Cambridge: Cambridge University Press, 2013), 177. 
uncover core tenets of Christian faith. ${ }^{8}$ However, the ultimate claim I will bring forth is that it was not Avicebron's supposed religious affiliation that was the decisive factor in attracting Eckhart to his philosophy, but rather its speculative and universal approach, metaphysically accounting for theological notions concerning God, creation, and man.

Although several scholarly works have been produced that concentrate on Avicebron's general reception history within High Scholasticism, ${ }^{9}$ there has been scarcely any attention devoted to Meister Eckhart's extensive usage of Fons vitae. Two scholarly works in which Eckhart's reception of Ibn Gabirol takes centre stage merit special attention, the first being the article entitled "Maître Eckhart et Avicébron" by the Swiss historian of philosophy Fernand Brunner published in $1991{ }^{10}$ In fact, this is the only article of its kind, inasmuch as it deals exclusively with this subject matter. Brunner offers a concise and profound overview of Eckhart's employment of Fons vitae in his Latin works (henceforth LW) as well as in his German ones (henceforth DW). The second is the article by Alessandro Palazzo entitled "Eckhart's Islamic and Jewish Sources: Avicenna, Avicebron, and Averroes" published in 2013. This article is the first major contribution to this topic in recent scholarship. Palazzo predicates his exploration of Eckhart's Jewish sources almost exclusively on Ibn Gabirol's Fons vitae, which entails an 11-page section that systematically tackles the theme at hand..$^{11}$ His study offers us a more detailed account of Eckhart's approach to Fons vitae throughout his writings than Brunner's. Through a statistical evaluation of Eckhart's quotations of Avicebron, Palazzo outlines, in a succinct and carefully thoughtout manner, the explicit mentions of Fons vitae in the corpus of Eckhart's works.

8 It was not unprecedented in the scholastic tradition to consider Avicebron to be a Christian thinker. See James A. Weisheipl, “Albertus Magnus and Universal Hylomorphism: Avicebron. A Note on Thirteenth-Century Augustinianism," in Albert the Great: Commemorative Essays, ed. Francis J. Kovach and Robert W. Shahan (Norman: University of Oklahoma Press, 1980), 244.

9 To mention a few: McGinn, "Ibn Gabirol: The Sage among the Schoolmen," 77-109; Jacob Guttmann, Die Scholastik des dreizehnten Jahrhunderts in ihren Beziehungen zum Judenthum und zur jüdischen Literatur (Breslau: M. \& H. Marcus, 1902), 1-46, 60-85, 154-67; Guttmann, Die Philosophie des Salomon ibn Gabirol (Göttingen: Vandenhoeck \& Ruprecht's Verlag, 1889), 39-65; Weisheipl, “Albertus Magnus and Universal Hylomorphism,” 239-60; Michael Wittmann, Die Stellung des hl. Thomas von Aquin zu Avencebrol (Ibn Gebirol) im Entwicklungsgang der arabischen Philosophie, in Beiträge zur Geschichte der Philosophie des Mittelalters, vol. 3.3, ed. Clemens Baeumker and Georg von Hertling (Münster: Aschendorff, 1900); John A. Laumakis, “Avicebron (Solomon ibn Gabirol) and Aquinas on Primary and Secondary Causality” (PhD diss., Marquette University, 2001); Mária Mičaninová, "Was Aquinas Right When He Claimed That Avicebron Departed from Aristotle?" Archive of the History of Philosophy and Social Thought 62 (2017): 281-305.

10 Brunner, "Maître Eckhart et Avicébron,” 133-39. Another noteworthy article, which I unfortunately came across too late, is Alessandra Beccarisi's "Zwischen Averroes, Avicenna und Avicebron. Meister Eckhart und die Noetik im Islam und Judentum,” in Christine Büchner, Markus Enders and Dietmar Mieth, eds., Meister Eckhart - interreligiös (Stuttgart: Kohlhammer, 2016), 223-40.

11 Palazzo, “Eckhart’s Islamic and Jewish Sources,” 271-81. 
In Eckhart's writings, one encounters explicit references to Fons vitae, but also several passages which implicitly exhibit similarities to Gabirolean notions. In his Latin works, Eckhart directly cites Avicebron on thirteen different occasions: ${ }^{12}$

- once in his Expositio libri Genesis (henceforth In Gen.I): (1) n. 27 [LW 1, 205.8-15]: FV 5:25 [301.20-302.1, 10-14];

- $\quad$ twice in his Liber parabolarum Genesis ${ }^{13}$ (henceforth In Gen.II): (2) n. 113 [LW 1, 580.2-4]: FV 1:3 [5.13-16], (3) n. 209 [LW 1, 684.5-685.4]: FV 5:24 [301.16-302.15];

- four times in his Expositio libri Exodi (henceforth In Ex.): (4) n. 58 [LW 2, 64.1213]: FV 5:23 [300.16], (5) n. 90 [LW 2, 93.11-13]: FV 5:23 [300.16-17], (6) n. 271 [LW 2, 218.13-219.2]: FV 5:43 [338.22-27], (7) n. 281 [LW 2, 225.5-12]: FV 1:4 [6.16-22, 24];

- once in Sermones et Lectiones super Ecclesiastici C. 24:23-31 (henceforth In Eccli.): (8) n. 9 [LW 2, 238.9-12]: FV 5:22 [298.18-21];

- on five separate occasions in Expositio sancti evangelii secundum Johannem (henceforth In Ioh.): (9) n. 263 [LW 3, 218.4-11]: FV 3:14 [108.19-20, 108.23109.3], (10) n. 389 [LW 3, 332.10-11]: FV 5:23 [300.16], (11) n. 463 [LW 3, 396.10-397.3]: FV 3:14 [108.19-20, 108.22-109.1], (12) n. 467 [LW 3, 399.9-10]: FV 3:14 [108.25-26], (13) n. 554: [LW 3, 483.13-484.3]: FV 2:9 [40.6-27], 2:10 [41.11-16], 3:4 [82.9-83.10].

Moreover-as Brunner revealed-two further parts of Eckhart's German sermons, rendering a philosophical conversation between a teacher (meister) and his pupil (jünger), echo specific sections from Fons vitae: DW 2, 612.3-10 [sermon 58]: FV 3:56 [204.10-13] and DW 3 302.3-14 [sermon 75]: FV 3:56-57 [204.13-205.18]. ${ }^{14}$ As in his treatment of Maimonides, Eckhart also entirely refrains from openly mentioning Ibn Gabirol in his Middle High German works. ${ }^{15}$ The critical edition of Eckhart's writings suggests the presence of numerous passages bearing resemblance to formulations and ideas found in Ibn Gabirol's Fons vitae. As Palazzo notes, some of these parallels come across as being rather coincidental, whereas others-such as LW 1,

12 Both Palazzo and Schwartz enumerate twelve explicit references by means of direct citations of Ibn Gabirol's Fons vitae in Eckhart's Latin writings: Palazzo, "Eckhart's Islamic and Jewish Sources," 272; Schwartz, "To Thee Is Silence Praise," 80; Schwartz, "Meister Eckhart and Moses Maimonides," 392. Eckhart's writings will be cited in brackets according to the critical edition: Meister Eckhart, Die deutschen und die lateinischen Werke, commissioned by the DFG, comprising Die deutschen Werke, ed. Josef Quint and Georg Steer, 5 vols. (Stuttgart: W. Kohlhammer Verlag, 1936-2016) (henceforth DW) and Die lateinischen Werke, ed. Konrad Weiss, Loris Sturlese, Albert Zimmermann, Joseph Koch, Heribert Fischer, Bruno Decker, Ernst Benz, Karl Christ, Bernhard Geyer, and Erich Seeberg, 5 vols. (Stuttgart: W. Kohlhammer Verlag, 1936-) (henceforth LW). McGinn alludes to the fact that Eckhart mentions Ibn Gabirol by name seventeen times.

13 Cf. Schwartz, "To Thee Is Silence Praise," 80.

14 Brunner, "Maître Eckhart et Avicébron," 133-39, 149.

15 McGinn, The Mystical Thought of Meister Eckhart, 267-68 n. 21. 
196.4-5 and LW 2, 64.6-7-are quite persuasive. ${ }^{16}$ In total, the editors of the critical edition of the DW and the LW suggest that there are nine sections in which Eckhart makes recourse to sections from Fons vitae in order to implicitly support his arguments:

- once in his Middle High German sermon 102 Ubi est, qui natus est rex Iudaeorum?: (1) [DW 4, 420.3 n. 31]: FV 1:3 [5.22-23];

- four times in his In Gen.I: (2) n. 12 [LW 1, 196.4-5 n. 3]: FV 3:22 [131.3], (3) n. 32 [LW 1, 210.3-4 n. 1]: FV 3:3 [81.17], FV 5:42 [335.9], (4) n. 36 [LW 1, 213.9-10 n. 3]: FV 5:11 [277.5-9], (5) n. 88 [LW 1, 246.6-7 n. 3]: FV 4:11 [236.11-237.9];

- twice in his In Gen.II: (6) n. 11 [LW 1, 483.1-3 n. 2]: FV 5:23 [300.16], (7) n. 197 [LW 1, 669.12-13 n. 2]: FV 1:3 [5.13-16.22];

- $\quad$ twice in his In Ex.: (8) n. 18 [LW 2, 24.2-4 n. 2]: FV 5:24 [301.16-302.15], (9) n. 58 [LW 2, 64.6-7 n. 2]: FV 4:13 [239.12-17].

\section{Emanation of the One or the Two? Avicebron's Fourfold Ordo Essendi}

On examining Eckhart's Opus tripartitum, one immediately encounters Ibn Gabirol's impact on it, seeing that the Dominican already reverts to his thought for his metaphysical reading of Gen 1:1:

Finally, it must be observed that it says "God" created "heaven and earth in the principle," two things, not more, such as three or four and so forth. It does not say that he created one thing. The reason is because by the fact that anything is or has been created it falls away from unity and simplicity. Unity and simplicity are proper to God and are his property, as I have written at length on the text "God is one" (Dt. 6:4; Gal. 3:20). Again, everything that falls away from the One, the First of all things, immediately falls into two and unto the other numbers by means of duality. And so Avicebron says that "the question 'whether a thing is' is asked in relation to the One because it is pure existence," "Under him the questions 'whether a thing is' and 'what a thing is' in the manner of duality belong to the intelligence, which is the first thing below God. In a threefold way the questions 'whether a thing is,' 'what it is,' and 'what sort it is' belong to the soul. In a fourfold way, the questions 'whether,' 'what,' 'what sort,' and 'why' a thing is belong to nature or the realm of generation that is below the soul. The fourth question refers to the first three." The first equal number, namely two, is the root of all division, plurality and number, just as the unequal or the One is the root and reason of lack of division ( $I n$ Gen.I n. 26-28 [LW 1, 205.1-206.4]). ${ }^{17}$

16 Palazzo, "Eckhart's Islamic and Jewish Sources," 272 n. 48.

17 Meister Eckhart, Meister Eckhart: The Essential Sermons, Commentaries, Treatises, and Defense, trans. Edmund Colledge and Bernard McGinn (New York: Paulist Press, 1981), 91. The printed translation uses the name "Ibn Gabirol," which I chaged to "Avicebron" since Eckhart did not know his true identity. For Eckhart as an interpreter of the book of Genesis, see Flasch, Meister Eckhart: Philosopher of Christianity, 115-30. 
In the quoted passage, Eckhart tackles the exegetical difficulty of providing a reason as to why God in His singularity initially calls into being two creations as opposed to one or any other number. He explains this problem away by employing the Avicebronian notion of the binarium famosissimum. ${ }^{18}$ The precept at hand, positing that from the first unified principle, two further principles emerge-those of form and matteris critical for the understanding of Ibn Gabirol's metaphysical undertaking. It entails Gabirolean hylomorphism, inferring a composite of a spiritual Materialprinzip (materia spiritualis/universalis) with a universal form (forma universalis) underlying all levels of the created realm. ${ }^{19}$ As Jacques Schlanger contends, this notion addresses the chief systematic objective of Gabirolean philosophy, reconciling the oneness of the Creator and the multiplicity of His created beings. ${ }^{20}$ Prior to quoting from Fons vitae, Eckhart seems to reiterate this Gabirolean notion, asserting that everything emanating from the One, it being the origin of the universe, must directly fall into the rank of the Two. If one keeps in mind Albertus Magnus's explicit Aristotelian rebuttal of this particular Avicebronian proposition, then Eckhart's acceptance thereof becomes even clearer. In the first book of his commentary on Liber de causis, a pseudo-Aristotelian paraphrase of Proclus's Elementatio theologica, ${ }^{21}$ Albert singles out this one tenet as the most problematic element underlying Avicebron's philosophy. ${ }^{22}$

Following his endorsement of this metaphysical view, Eckhart then quotes a passage from the fifth chapter of Fons vitae (section 24), a section of which he seems particularly fond, citing it on three different occasions. In this passage, which resembles a Präpositionsmetaphysik, ${ }^{23}$ Ibn Gabirol lays out his Neoplatonic outlook in an

18 See Paul V. Spade, "Binarium Famosissimum," in The Stanford Encyclopedia of Philosophy (Fall 2008 Edition), ed. Edward N. Zalta, https://plato.stanford.edu/archives/fall2008/entries/bina rium/; Pessin, Ibn Gabirol's Theology of Desire, 186-88; McGinn, “Ibn Gabirol: The Sage among the Schoolmen," 86-87, 96-97.

19 For detailed explanations of Gabirolean hylomorphism, see Pessin, Ibn Gabirol's Theology of Desire, 66-90, 106-12, 165-88; Schlanger, The Philosophy of Solomon Ibn Gabirol, 177-218; Nicola Polloni, "Toledan Ontologies: Gundissalinus, Ibn Daud, and the Problems of Gabirolian Hylomorphism," in Appropriation, Interpretation and Criticism: Philosophical and Theological Exchanges Between the Arabic, Hebrew and Latin Intellectual Traditions, ed. Alexander Fidora and Nicola Polloni (Barcelona: FIDEM, 2017), 19-49. For an analysis of Albertus Magnus's critique of this specific metaphysical tenet of Avicebronian philosophy, see McGinn, "Ibn Gabirol: The Sage among the Schoolmen," 97.

20 Schlanger, The Philosophy of Solomon Ibn Gabirol, 135.

21 Cf. Yossef Schwartz, "Die Rezeption philosophischer Schriften aus dem Judentum," in Grundriss der Geschichte der Philosophie. Die Philosophie des Mittelalters IV: 13. Jahrhundert, ed. Peter Schulthess and Christoph Flüeler (Basel: Schwabe Verlag 2017), 1:206-16.

22 Albertus Magnus, Buch über die Ursachen und den Hervorgang von allem aus der ersten Ursache: Liber de causis et processu universitatis a prima causa, ed. and trans. Henryk Anzulewicz, Maria Burger, Silvia Donati, Ruth Meyer, and Hannes Möhle (Hamburg: Felix Meiner Verlag, 2006), 46. See Kurt Flasch, Meister Eckhart. Die Geburt der "Deutschen Mystik" aus dem Geist der arabischen Philosophie, 2nd ed. (Munich: Beck, 2008), 82-83.

23 See, for example, Philo's Cher. 125-27. For a further examination of Präpositionsmetaphysik in relation to Philo and Jewish and Christian sources in antiquity, see Gregory E. Sterling, "Prepositional 
interrogative fashion, supplying the answers through the order of the first four natural numbers. These in turn epitomise the four respective metaphysical principles and ranks of being (God, intellect, soul, and nature). ${ }^{24}$

It is still not quite clear how Ibn Gabirol's explanation of the fourfold structure of being aligns with his specific reading of Gen 1:1 here. However, the previous paragraphs provide an indication. Actually, In Gen.I n. 24-25 is the point of departure for Eckhart's drawing on Avicebron. There, he symbolically equates the creation of heaven and earth with that of form and matter, arguing that the latter pair also came into being simultaneously. Eckhart then goes on to ascribe activity to form and, accordingly, passivity to matter, the first inhabiting the higher realm, the latter the lower one..$^{25}$ This may be the point that Eckhart aims to highlight: Ibn Gabirol assigns the universal intellect, representing the category of the Two, this specific ontological rank, inasmuch as its innate structure comprises of genus and differentia, both fundamental categories denoting form and matter, ${ }^{26}$ which in turn make up its being. ${ }^{27}$ Moreover, one need look no further than the concluding remark of section 23 in chapter 5 of Fons vitae in order to observe that Ibn Gabirol's framework is almost identical to Eckhart's. In it, the magister sets out to answer the basic question as to why matter and form come into being, the answer supplying the groundwork for the subsequent discussion in the following section (24). ${ }^{28}$ The passage at hand depicting God's productive essence as the One from which the twofold reality comprised of matter and form emerges is quite revealing, inasmuch as it seems to

Metaphysics in Jewish Wisdom Speculation and Early Christological Hymns," Studia Philonica Annual 9 (1997): 219-38. As Altmann and Stern note, a similar presentation is already present in Isaac Israeli's Book of Definitions, in Isaac Israeli. A Neoplatonic Philosopher of the Early Tenth Century, trans. Alexander Altmann and Salomon M. Stern (Chicago: University of Chicago Press, 2009), 23. See also Pseudo-Aristotle, The Theology of Aristotle, 5:30-52, trans. Geoffrey Lewis, in, Plotini Opera. Tomus II: Enneades IV-V, ed. Hans-Rudolf Schwyzer and Paul Henry (Oxford: Oxford University Press, 1977), 437-39 (henceforth ThA). Cf. Schlanger, The Philosophy of Solomon Ibn Gabirol, 87-89, 98.

24 FV 5:24 [301.20-302.1, 302.10-14]. For the English translation, see Solomon ibn Gabirol (Avicebron), The Font of Life (Fons Vitae), trans. John A. Laumakis (Milwaukee: Marquette University Press, 2014), 270 (henceforth FL). In chapter 1 of Fons vitae (section 16 [20.15-17]), Ibn Gabirol also discusses matter and form in relation to both the heavenly realm and the earthly one, though he rather contends that their mergence takes place in both ontological realms. For further similar depictions in Fons vitae, see FV 4:11 and 4:13. For Ibn Gabirol's Neoplatonic theory of creation, see Yossef Schwartz, "Salomon Ibn Gabirol: Zwischen Schöpfungsmythologie und Geheimnis der Einheit," in Platonismus im Orient und Okzident: Neuplatonische Denkstrukturen im Judentum, Christentum und Islam, ed. Raif G. Khoury, Jens Halfwassen, and Frederek Musall (Heidelberg: Universitätsverlag Winter, 2005), 144-59; Schlanger, The Philosophy of Solomon Ibn Gabirol, 229-42.

25 LW 1, 204.1-16. See Burkhard Mojsisch, Meister Eckhart: Analogy, Univocity and Unity, trans. Orrin F. Summerell (Amsterdam: B.R. Grüner, 2001), 70-71, 105.

26 For the definitions of universal matter and form, see FV 1:10 [13.23-14.5], 1:13 [16.9-13].

27 See, for example, FV 3:41 [172.10-20]; 4:6 [223.17-224.1] 5:12 [279.6-19]. For the unifying and dynamic feature of the divine Will in relation to universal matter and form, see FV 2:13 [46.2-12]. 28 FV 5:23 [300.14-26]. 
constitute a great deal of Eckhart's metaphysical understanding and approach to Gen 1:1 in In Gen.I n. 24-28. Ibn Gabirol's passage reads as follows:

S. Why did matter and form exist?

T. Because of the first essence and its property. Moreover, two was placed under the One, and they are the expressions of it, and if what was created were one, there would be no difference here, because difference is found only under the One. Moreover, because non-being does not have form, it is necessary that being has form. Moreover, since being needed to be finite in itself, it is necessary that it should be made finite by form, because a form is what encompasses a thing. Moreover, since the first acting unity does not have hyle, it is necessary that the unity that follows this one should consist of hyle. Hence, it receives unity and is made two, that is, subjected hyle and sustained unity. Moreover, since the first unity is a self-sufficient agent, it is necessary that the unity that follows it needs what sustains it. Hence, there must by hyle here that sustains it, and consequently, two come to be (FV 5:23 [300.14-26]). ${ }^{29}$

The way in which Eckhart characterises matter and form, the two building blocks of reality, in this context also bears a resemblance to Ibn Gabirol's conceptualisation thereof: (1) Like Ibn Gabirol, ${ }^{30}$ Eckhart posits the passivity of matter ${ }^{31}$ and the activity of form. (2) Eckhart infers the ontological priority of form over matter in a manner similar to descriptions found in Fons vitae. ${ }^{32}$ While Ibn Gabirol usually portrays form as occupying the higher noetic realm, in his empirical diversification, he often relegates matter to the lowest ontological level..$^{33}$ (3) Eckhart's emphasis laid on the creatio simultanea of matter and form is a feature that conforms well to Avicebronian thought. On numerous occasions, Ibn Gabirol underpins the fact that God is above time and eternity and therefore that His creative activity is not constrained to the realm of time. (4) Eckhart's specific terminology used to account for worldly divisibility in light of the indivisibility of God's unity by means of numerological argumentation is reminiscent of Gabirolean thought. Following his quotation of Avicebron, Eckhart links the "root of division of all things" (radix omnis divisionis) to the

29 FL 239 (emphasis in original).

30 See, for example, FV 2:9 [40.6-27].

31 See Brunner, "Maître Eckhart et Avicébron," 149.

32 See, for example, FV 2:9 [40.6-27], 4:11 [236.5-237.17]. For an analysis of this Gabirolean theme, see Schlanger, The Philosophy of Solomon Ibn Gabirol, 161; McGinn, "Ibn Gabirol: The Sage among the Schoolmen," 87-89.

33 The critical edition of Eckhart's LW alludes to the overlap of features (1) and (2) in In Gen.I n. 32 [LW 1, 210.3-4 n. 1] ("Inferiora autem passiva sunt, informia et nuda"). Two passages from Fons vitae are quoted in this respect: FV 3:3 [81.17] ("Omne quod est, quanto superius est, tanto formae similius est") and 5:42 [335.9-11] ("Forma unenit a superiore, et materia eam recipit ab inferiore, quia materia est subiecta, per hoc quod habe esse sub forma, et forma est sustentata super eam"). The additional notion here that is similar to Ibn Gabirol's Fons vitae is that the ideas perfect matter: "perficere essentiam illius in quo est" (FV 1:13 [16.10-11]; emphasis in original; cf. also FV 1:13 [16, 17], 2:10 [60.2861.3], 3:36 [161.20-162.1], 4:10 [233.17-19]). For a detailed presentation of the ontological difference between matter and form in Gabirolean philosophy, see Schlanger, The Philosophy of Solomon Ibn Gabirol, 141-46. 
concept of the first even natural number, the Two, ${ }^{34}$ and the notion of strict indivisibility to the first uneven natural number, the One. ${ }^{35}$ In Fons vitae, one encounters various such lines of argumentation using similar jargon. ${ }^{36}$ Eckhart's wording in this respect, speaking of the Two-that is, matter and form-in terms of radix omnis divisionis also stands out. In a key section (11) of chapter 4 of Fons vitae, Ibn Gabirol specifically describes matter as epitomising the nature of the Two and as being, by virtue thereof, the root of all divisibility. Accordingly, he renders matter together with form-with both of them together conforming to the nature of the uneven number three-the ultimate radix omnium. ${ }^{37}$ Interestingly, the critical edition of Eckhart's works does not allude to the possible correlation here, but to a similar correlation in In Gen.I n. 88 [LW 1, 246.6-7]. In this section, Eckhart attempts to explain why in Gen 1:8b, the second day of creation does not end with God's otherwise usual concluding proclamation that it was good. In order to account for this exegetical difficulty, Eckhart once again reverts to the metaphysical idea that the Two is the root of all division ("binaries radix est et origo omnis divisionis"), claiming that in this instance, division embodies evil. ${ }^{38}$ Eckhart concludes his ontological view on the subject with the assertion that the Two and division are always a falling from being. ${ }^{39}$

At this thematic conjuncture and against this backdrop, another remark in the critical edition of Eckhart's LW concerning his reading of Gen 1:2 (“tenebrae errant super faciem abyssi”) attracts our attention. In In Gen.I n. 36, Eckhart explicates the ontological potentiality (potentia) of matter in terms of being lacking in form ("privatio formae"). ${ }^{40}$ As Konrad Weiss suggests, ${ }^{41}$ this depiction closely resembles a section from chapter 5 of Fons vitae:

Consider the privation of matter to be like the darkness of air, and consider form in it to be like light. And consider dark air as having being in itself and as having the being of light in potency when it lacks light. Similarly, consider that matter has being in itself and has being in potency when it lacks form, and that being is produced from the joining of matter and form. ${ }^{42}$

34 Cf. In Gen.I n. 88 [LW 1, 246.6-7].

35 In Gen.I n. 28 [LW 1, 205.16-206.4].

36 See, for example, FV 4:14 [242.8-24].

37 FL 203: "Moreover, in its first division, matter is divided into two parts according to the nature of two, namely, into the matter of the simple substances and into the matter of composite substances. The property of two, therefore, also belongs to it in this way.-Therefore, it is now clear to you that form is likened to one and matter to two. And since this is so and matter and form are the root of all things, it is, therefore, clear that three is the root of all things [et materia et forma sunt radix omnium: ergo manifestum est quod tria sunt radix omnium]" (FV 4:11 [237.9-17]). See McGinn, "Ibn Gabirol: The Sage among the Schoolmen," 79.

38 The editors provide the following passage from Fons vitae: FV 5:11 [236.18-237.9].

39 In Gen.I n. 90 [LW 1, 248.15-16].

40 In Gen.I n. 36 [LW 1, 213.9-10].

41 LW 1, 213 n. 3.

42 FL 226: FV 5:11 [277.5-10]. Weiss specifically refers to Fons vitae 5:11 [277.5-9]. Weiss also mentions Eckhart's In Ioh. n. 440 [LW 3, 378.5-6] and 492 [LW 3, 424.7-11], which appears to echo Ibn Gabirol's 
The similarity becomes even more prominent if one accounts for Eckhart's symbolic exegesis of the darkness hovering over the abyss. The darkness, as he explains, is to be understood in terms of deprivation of light, while the abyss manifests the shapeless prima materia. ${ }^{43}$ If we develop the logical consequence of this Eckhartian depiction further, then light, accordingly, represents form. If our purported reading holds true here, then this reveals that the LW aligns Augustine's view of matter (in book 12 of his Confessions) with the premises of Gabirolean hylomorphism. ${ }^{44}$

In Eckhart's reading of Gen 1:1 in In Gen.II n. 11, the Gabirolean binarium famosissimum appears to recur. In this section, he aims to account for diversity within the created realm by stating that it is in keeping with the nature of the Two, typified by God's simultaneous creation of heaven and earth. ${ }^{45}$ His Neoplatonic line of thought is quite straightforward: while no form of multiplicity can be present within the category of the One, anything that stems from it-hence occupying an ontological realm outside of it-conforms to the category of the Two. In this way, Eckhart clarifies Augustine's dichotomous view of God's creation of the heavens and the earth in section 7 of book 12 of his Confessions. ${ }^{46}$ A brief analysis of section 23 of chapter 5 of Fons vitae suffices to discern the parallels it bears with Eckhart's rendition of the thought pattern of binarium famosissimum: "And if what was created were one, there would be no difference here, because difference is found only under the One." 47

The editors of the LW are correct in drawing support for their purposed linkage of In Gen.II n. 11 to this specific passage from Fons vitae by alluding to In Ioh. n. 389.48 There, within an exegesis of John 4:38, ${ }^{49}$ Eckhart explicitly refers to Ibn Gabirol's assertion that each differentiation occurs under the One ("omnis differentia sub uno est”) in Fons vitae 5:23. ${ }^{50}$ Admittedly, the context in which Eckhart employs this Gabirolean idea is entirely different. However, more importantly, it uncovers Eckhart's

attitude towards matter as pure potentiality and as a deficiency of form. Eckhart's depiction of matter's lack of form in terms of a throne (In Ioh. n. 36 [LW 1, 213.11-12]) in the same paragraph, a metaphor which can be found in Fons vitae 5:42 [335, 22-24], is also striking. See Schlanger, The Philosophy of Solomon Ibn Gabirol, 53.

43 In Gen.I n. 35 [LW 1, 212.4-5].

44 For the correlation of Augustine (and Boethius) with Ibn Gabirol's Fons vitae within High Scholasticism, see McGinn, "Ibn Gabirol: The Sage among the Schoolmen," 93, 95.

45 In Gen.II n. 11 [LW 1, 482.8-10].

46 Augustine, St. Augustine's Confessions in Two Volumes, trans. William Watts (London: William Heinemann; Cambridge, MA: Harvard University Press, 1912), 2:269-71: "For you are almighty and good in making all things good, the great heaven and the small earth: two entities [duo quaedam], one near to you, the other near to nothing. You alone would be greater than the one, while nothing would be lesser than the other."

47 FL 239: FV 5:23 [300.14-20].

48 LW 1, 483 n. 2.

49 "Ego misi vos metere quod vos non laborastis: alii laboraverunt, et vos in labores eorum introistis."

50 In Ioh. n. 389 [LW 3, 332.11]. 
view thereof as a true metaphysical precept. With the aid of this Avicebronian axiom, he can reinforce, ex negativo, the unification of the faithful man with God by means of his love of Him. ${ }^{51}$

As Konrad Weiss aptly observes, Eckhart appears to resort to an Avicebronian precept at the outset of In Gen.I (n. 12), in a further metaphysical rationalisation of Gen 1:1, attempting once more to explain how multiplicity emerges from the One. ${ }^{52}$ Conceding that from the One, nothing other than a thing that is one in essence can emerge, Eckhart accounts for the multiplicity of God's creation by putting forward the claim that the universe, notwithstanding God's ostensible plurality of forms, is one in nature. ${ }^{53}$ He proceeds to apply this contention to God, arguing in analogous terms that God is also purely one in light of His attributes of being, life, thought, and activity. ${ }^{54}$ Eckhart's dependence upon Fons vitae at this juncture does not become evident until he makes the metaphysical assertion that the simpler and more perfect an existing thing is, the more diverse it is in relation to its powers:

Debet necessario ut omnis causa sit imprimens Ubi notandum primo quod, quanto res est perfecfiguras suas et formas in suo causato. et nullum tior in esse et simplicior, tanto copiosior est seimpressum est tale quale id a quo imprimitur in cundum rationes et potentias (In Gen.I n. 12 fortitudine et perfectione. et substantia simplex [LW 1, 196.4-5]; my emphasis).

causa est compositae. ergo debet necessario ut substantia simplex sit plurium figurarum et formarum quam substantia composita (FV 3:22 [130.25-131.4]; my emphasis).

Through this argument, Ibn Gabirol endeavours to show that the substantia simplex, such as the universal intellect that encompasses all forms, ${ }^{55}$ constitutes a structure of totality which entails all of created reality within it. ${ }^{56}$ However, not only does Eckhart's claim itself bear a resemblance to the Gabirolean one, but so too does the example he adduces for it. Eckhart moves on to contrast the rational soul with the forms of matter, maintaining that the substance of the soul is more unified than any material form, while its powers are more diverse. ${ }^{57}$ An examination of the next section (23) of Fons vitae's chapter 3 reveals the fact that Ibn Gabirol alleges almost the exact same example for his contention. In connection with the soul, he also dem-

51 Brunner underpins this fact here: "Maître Eckhart et Avicébron,” 146. Cf. Flasch, Meister Eckhart: Philosopher of Christianity, 108.

52 LW 1, 196 n. 3. Cf. LW 1, 194.7-8. Palazzo also evaluates this passage's link to Fons vitae as being one of "the most convincing ones among those suggested by the editors of Eckhart's Opera omnia" (Palazzo, "Eckhart’s Islamic and Jewish Sources,” 272 n. 48).

53 In Gen.I n. 12 [195.10-196.3].

54 In Gen.I n. 12 [195.12-196.2].

55 See Schlanger, The Philosophy of Solomon Ibn Gabirol, 194-95.

56 See, for example, FV 2:3 [30.6-20], 3:9 [98.24], 3:22 [131.14-17], 3:23 [132.22-133.6], 3:24 [137.26-27], 3:32 [153.1-4, 154.15-155.6].

57 In Gen.I 12 [196.5-8]. 
onstrates that the spiritual elemental substance (substantia simplex spiritualis) is "better suited for gathering many forms in itself than is a corporeal composite substance." 58 If our tracing of Eckhart's contention to Fons vitae holds true here, then this means that he had aptly grasped Gabirolean thought as ultimately being a metaphysics of the One. That is to say, Eckhart would thereby be indicating that in the final analysis, Avicebron does not subscribe to the precept of the binarium famosissimum, but rather to the notion of the primary unity from which a further unity emerges, albeit one that is created and ontologically subordinated to the first. ${ }^{59}$

\section{The Soul's Intellectual Ascent to the Noetic Realm}

Eckhart is by no means exclusively interested in Ibn Gabirol's abstract metaphysical premises: he is also interested in their anthropological framework; in the final goal of the human soul, which is its reunification with its pure counterpart, the higher world. ${ }^{60}$ The following point of interest finds its apt expression in In Gen.II n. 113. In his Philonic reading of Gen 2:18 ("Non est bonum hominem esse solum, faciamus ei adiutorium simile sibi”)-with man epitomising the faculty of reason (intellectus) while his female counterpart epitomises that of sensual perception (sensitivum) ${ }^{61}$ Eckhart adduces an idea from the third section of chapter 1 of Fons vitae for his exegesis. He specifically quotes Ibn Gabirol's contention "that the perfection of the soul is its knowledge, whereas its imperfection is its ignorance [...]. And [...] from its beginning in this world, the soul is changed from ignorance to knowledge and thus goes forth from potency to act." ${ }^{62}$ In fact, this citation seems to constitute an important reference point for Eckhart's claim that sense perception is indispensable for the initial phases of the intellectual actualisation of the human soul. ${ }^{63}$ Ibn Gabirol depicts this intellectual process in Aristotelian terms, as a transition from potentiality to actuality, which in turn means the transition from ignorance to knowledge. However, he places this Aristotelian portrayal as part of a broader Neoplatonic theme of the soul's intellectual ascent to the divine realm. As the Andalusian philosopher proclaims from the outset, the subject at hand, providing the answer as to why God created man, actually marks the focal thread running through the entire metaphysical

58 FL 141: FV 3:22 [131.23-24]. See FV 3:23 [132.5-17].

59 See, for example, FV 2:20 [60.18-62.9], 4:13-14 [238.23-245.4], 5:23 [300.23-26].

60 See, for example, FV 1:2 [4.24-25]. See Schlanger, The Philosophy of Solomon Ibn Gabirol, 2-4.

61 For the influence of Philo's allegorical reading of Adam and Eve on the Church Fathers, see David

T. Runia, Philo in Early Christian Literature: A Survey (Assen: Van Gorcum; Minneapolis: Fortress Press, 1993), 309, 352.

62 It is noteworthy that in the original text, the passage in question appears in the interrogative form: FL 63 (FV 1:3 [5.3-16]).

63 In Gen.II 113 [LW 1, 580.5-6]: "Hoc autem fit ministerio sensuum, sensitivi scilicet." 
examination of Fons vitae. ${ }^{64}$ Thus, the critical edition of the LW is correct in noting ${ }^{65}$ that a similar depiction is found in Eckhart's allegorical reading of the expression “duae gentes" (Vg. Gen 25:23) in In Gen.II n. 197, by which God alludes to Rebecca's impending delivery of Jacob and Esau. ${ }^{66}$

Drawing upon the invocation of Avicebron in In Gen.II n. 113, the critical edition of the DW notes that Eckhart may have intended to echo this Gabirolean idea once again in his German sermon 102, ${ }^{67}$ claiming "Got hât den menschen gemachet, daz er wizze." 68 This appears to be Ibn Gabirol's unequivocal answer to the question of why God created man in Fons vitae 1:3: "It follows that the end and aim of the creation of man is for his conscious knowing to develop from potentiality to actuality." 69 Yet it could also be the case that Eckhart is simply giving voice to a theological premise prevalent among Dominican circles of his day. However, the clear-cut manner in which Eckhart brings forth this argument would suggest otherwise, since it seems to be distinctively Gabirolean.

Palazzo rightfully points to the thematic correlation between Eckhart's citation of Ibn Gabirol in In Gen.II n. 113 and his implicit citations from Fons vitae in sermons 58 (FV 3:56 [204.10-13]) and 75 (FV 3:56-57 [204.13-205.18]). All three references to Fons vitae pivot around Ibn Gabirol's theme of the soul's intellectual ascent to the upper world. Sermon 75 is particularly interesting in view of Eckhart's invocation of Ibn Gabirol in his interpretation of John 4:38. The theological foundation of this reference was the attainment of a unio mystica through divine love. In the German sermon at hand, this is where Eckhart's employment of Fons vitae takes its departure: in order to attain the perfect love and subsequently unify with God's being, one must first be endowed with the ûfklimmenden geist, through which the individual can spiritually ascend to the Godly realm. ${ }^{70}$ Even though Ibn Gabirol does not directly deal with the theme of the soul's amor Dei in these specific instances, Eckhart was most likely aware of its significance within the overall framework of the Avicebronian metaphysics of longing. Section 32 of chapter 5 of Fons vitae revolves, for example,

\footnotetext{
64 FV 1:1 [2.8-10], 1:2 [3.30-4.9], 1:3 [5.22-25], 2:6 [36.6-14]. On Eckhart's connection of Avicenna with Ibn Gabirol at this juncture, see the insightful remarks by Palazzo: "Eckhart's Islamic and Jewish Sources," 276-77. Cf. also Brunner, "Maître Eckhart et Avicébron,” 141; Schlanger, The Philosophy of Solomon Ibn Gabirol, 243-46.

65 LW 1, 669 n. 2.

66 After his interpretation of the duae gentes in Rebecca's womb as the two respective tendencies innate to the human soul, the sensual (Esau) and the rational (Jacob) (In Gen.II 196 [LW 1, 668.8669.11]), Eckhart proceeds to present them both in terms of knowledge and ignorance ("duae gente in nobis sunt [...] scientian et ignorantia”).

67 DW 4, 420 n. 31.

68 DW 4, 420.127.

69 FL 6 [5.22-23].

70 Cf. Palazzo's apt description of this passage: “Eckhart's Islamic and Jewish Sources,” 277-78. Cf. Brunner, "Maître Eckhart et Avicébron,” 135-39.
} 
around the notion of all things ascending towards the goodness of the transcendent One, a drive stemming from their fundamental desire for unity. ${ }^{71}$

However, whereas Eckhart exploits these Avicebronian portrayals to buttress man's viable epistemological prospect of a spiritual union with God's being, Gabirolean philosophy certainly does not wish to go this far. Despite the ultimate striving to be at one with God's primary being that is intrinsic to the human soul, Ibn Gabirol restricts the pinnacle of its attainable intellectual endeavours to its unification with the noetic realm. ${ }^{72}$

Another noteworthy feature of this Eckhartian reference to Ibn Gabirol in the DW is the fact that he also deems it important to disclose the means by which Fons vitae conveys these theoretical notions: through an intellectual instruction between a magister and his discipulus. This may show that Eckhart considered the dialogical form of Fons vitae to have a special pedagogical thrust, which proved effective within the framework of the religious instruction in his sermons. Eckhart's German sermon 58 also underpins this hypothesis, for there he quotes passages from Fons vitae in their original literary form as part of a lesson between a meister and his jünger.

\section{A Gabirolean Reading of the Gospel of John's Metaphysics of the Verbum}

Eckhart's insertion of Avicebron's philosophy into a distinctly Christian theological discourse finds its culmination in his reading of the prologue of the Gospel of John (1:1-2). ${ }^{73}$ At this thematic juncture, we find a perplexing passage in In Ioh. n. 47:

From a careful investigation of what Augustine said, we can understand what the second book of the Posterior Analytics says: "The questions we ask are equal in number to the things we truly know." We can ask about things whether they are, what sort they are, what they are and why they are. The four passages we have here answer these in order. "In the beginning was the Word" gives you the fact that the thing exists, for he says that it "was." What sort of thing the Word is, is pointed out in what follows, "and the Word was with God." This will be made

71 FV 5:32 [317.4-12]. For further analysis of this Gabirolean theme, see Schwartz, "Salomon Ibn Gabirol," 157-59; Warren Zev Harvey, "Filosofía y poesía en Ibn Gabirol," Anuario Filosófico 33, no. 2 (2000): 491-504 (I would like to thank Harvey for giving me the English translation of this article). For a systematic treatment of the subject of desire in Gabirolean metaphysics, see Pessin, Ibn Gabirol's Theology of Desire, especially 15-52, 66-90; Schlanger, The Philosophy of Solomon Ibn Gabirol, 213-19.

72 Brunner points to $T h A$, specifically $T h A 1, \S \S 21-42$ [Enn. 4.8.1], as the possible source at the root of these Gabirolean depictions: "Maître Eckhart et Avicébron," 138-39. Cf. Schlanger, The Philosophy of Solomon Ibn Gabirol, 64.

73 On Eckhart's intention in his philosophical reading of the Gospel of John as a whole, see Flasch, Meister Eckhart: Philosopher of Christianity, 166-89. 
clear below. What the Word is follows in the text, "the Word was God.” The reason why is shown when it says, "this Word was in the beginning with God" (LW 3, 39.1-8). ${ }^{74}$

On examining the passage in question, one might justifiably ask how this even relates to Ibn Gabirol. On the face of it, Eckhart is merely citing the opening sentence of book 2 of Aristotle's Posterior Analytics. Yet a closer look at it exposes-as the critical edition of the LW notes ${ }^{75}$-that in fact, it partially has its origin in Fons vitae 5:24. The Dominican master begins by simply citing the opening assertion of An. post. $2.89 \mathrm{~b} 23$, which reads: "Quaestiones sunt aequales numero his, quaecumque vere scimus."76 However, Eckhart proceeds to predicate his detailed presentation of the questions themselves on Fons vitae 5:24 [301.18]:

Est autem quaestio de rebus: an Dico quod esse ab extremo supre- Quaerimus autem quatuor: sint, quales sint, quid sint, et mo usque ad extremum infimum quia, propter quid, si est, quare (In Ioh. n. 47 [LW 3, 39.3]). distinctum est quatuor ordinibus, quid est (An. Post. 2.89b23). scilicet an est, quid est, quale est, quare est (FV 5:24 [301.16-18]).

This unexpected use of section 24 of chapter 5 of Fons vitae, a section with which Eckhart was very familiar, appears to be anything but coincidental. This passage prompts the following three inferences: (1) The fact that Eckhart draws upon Ibn Gabirol without explicitly mentioning him does not diminish Ibn Gabirol's significance within his body of thought. On the contrary, it would rather suggest that the impact of Gabirolean philosophy on Eckhart was so profound that he-possibly even unknowingly-uses it to complete Aristotelian ideas. Bearing such non-explicit invocations in mind, one may be tempted to put forward the claim that Eckhart not only read Fons vitae firsthand-as Palazzo convincingly contends ${ }^{77}$-but that he even knew several sections of it by heart. (2) One must also account for the particular context in which Eckhart makes use of Fons vitae: an interpretation of the two opening verses of the prologue of the Gospel of John, whose sense he aims to uncover by allusion to the sixth chapter of book 8 of Augustine's On the Trinity (section 10). He then, in turn, goes on to elucidate Augustine's portrayal of the soul's intuitive inner

74 Meister Eckhart: The Essential Sermons, Commentaries, Treatises, and Defense, 138.

75 See the remark by the editors of the LW: "Quattuor hae quaestiones non sunt eaedem quas Aristoteles I. c. enumerate (quaerimus autem quattuor: quia, propter quid, si est, quid est), sed quas Avencebrol point, Fons vitae V. c. 24" [emphasis in original]. Cf. Niklaus Largier's remark, seemingly based on the verdict of the critical edition: " 532,8 an < .. > quare] In den vier Fragen folgt Eckhart, obwohl er sie Aristoteles zuschreibt, nicht diesem, sondern Avencebrol, Fons vitae V c.24” [emphasis in original] (Meister Eckhart: Werke II, ed. Niklaus Largier, trans. Josef Quint [Frankfurt am Main: Deutscher Klassiker Verlag, 1993], 866).

76 Aristotle, Posterior Analytics. Topica, trans. Hugh Tredennick and E.S. Forster (Cambridge, MA: Harvard University Press, 1960), 174-75.

77 Palazzo, "Eckhart’s Islamic and Jewish Sources," 273. 
knowledge of its own being ${ }^{78}$ by making recourse to Aristotle's An. post. 2.89b23. Eckhart employs Ibn Gabirol at a point intersecting with the most crucial sources of his Christian philosophy: the prologue of the Gospel of John and the two most cited thinkers in his oeuvre, Augustine and Aristotle. Against this background, Avicebron's centrality to Eckhart's thought becomes all the more evident. (3) More importantly, the Dominican appears to apply the four Aristotelian inquiries, in their Gabirolean incarnation, to John 1:1-2 in a similar fashion to Fons vitae 5:24. That is to say, Eckhart adopts this method for the purpose of outlining his speculative worldview. Taking his cue from Avicebronian metaphysics, Eckhart implements the Aristotelian questions in his Neoplatonic reading of Vg. John 1:1-2: “In principio erat Verbum” provides an answer to the initial question of whether the Word even exists. The subsequent statement "et Verbum erat apud Deum” yields the Word's essence. The third assertion "et Deus erat Verbum" discloses the inner makeup of the divine Word. The concluding formulation "hoc erat in principio apud Deum" reveals the reason for its existence. $^{79}$

Of course, one may dismiss this proposed comparison with Ibn Gabirol's philosophy, arguing that Eckhart's exegesis here does not exhibit any distinct Neoplatonic features. Given, however, the broader scope of his understanding of the prologue of the Gospel of John, one may raise the following three objections: (1) Eckhart describes the Word's coming into being in emanatistic terms, as perpetually overflowing from God the Father. ${ }^{80}$ From this perspective, one may liken this employment of Fons vitae 5:23 to the one in In Gen.I n. 26-28, inasmuch as both deal with basic questions emerging from Scripture pertaining to the creation of the universe. ${ }^{81}$ (2) Like Ibn Gabirol in Fons vitae's chapter 5, Eckhart, in sections 1 to 51 of In Ioh., quite often equates the divine Word with the universal intellect. ${ }^{82}$ (3) Although the Dominican applies the four questions exclusively to the Word, he still appears to want to depict a different ontological stage of its unfolding with each respective an-

78 See Augustine, On the Trinity: Books 8-15, ed. Gareth B. Matthews, trans. Stephen McKenna (Cambridge: Cambridge University Press, 2002), 16. See Flasch, Meister Eckhart: Philosopher of Christianity, 181.

79 Cf. Jens Halfwassen, "Ein Meister der Philosophie. Neue Literatur zu Meister Eckhart," Philosophische Rundschau 58 (2011): 172-73.

80 In Ioh. nn. 8 [LW 3, 8.10-13], 25 [LW 3, 20.5-6], 27 [LW 3, 21.28], 35 [LW 3, 29.6-30.9] 56 [LW 3, 46.13-47.1], 82 [LW 3, 70.6-8]. See also In Ioh. nn. 185 [LW 3, 154.9-14], 342 [LW 3, 291.6-9], 489 [LW 3, 489.10-12], 546 [LW 3, 492.9-12]. See Brunner, "Maître Eckhart et Avicébron," 145; Flasch, Meister Eckhart: Philosopher of Christianity, 185.

81 For Eckhart's strong correlation of the account of the creation with the prologue of the Gospel of John, see Flasch, Meister Eckhart: Philosopher of Christianity, 41.

82 In Ioh. n. 34 [LW 3, 27.12-28.3]. For the Neoplatonic thought pattern of the universal intellect in Eckhart's philosophy, see Jens Halfwassen, "Gibt es eine Philosophie der Subjektivität im Mittelalter? Zur Theorie des Intellekts bei Meister Eckhart und Dietrich von Freiberg," Theologie und Philosophie 72 (1997): 338-60; Halfwassen, “Gott als Intellekt: Eckhart als Denker der Subjektivität,” Meister-Eckhart-Jahrbuch 5 (2011): 13-25. 
swer. Taking this view, one may further develop this claim by aligning Eckhart's reading of John 1:1-2 with Ibn Gabirol's application of the four questions to reality's fourfold order of being in Fons vitae 5:24: ${ }^{83}$

- Existence (ei esti/an est): John 1:1a, signifying the Word in its original coexistence with God.

- $\quad$ [Existence,] quiddity (ti esti/quid est): John 1:1b, signifying the Word's manifestation as intellect.

- [Existence, quiddity,] quality (to hoti [hopoion ti esti]/quale est): John 1:1c, signifying the Word's embodiment as the soul. ${ }^{84}$

- [Existence, quiddity, quality,] quality (to dioti [ti dia esti]/quare est): John 1:2, signifying the Word's epitome of the physical world. ${ }^{85}$

Even in light of this comparison, the difference between Eckhart's ontological scheme and that of Ibn Gabirol is still substantial and in some aspects simply irreconcilable. In stark contrast to Ibn Gabirol, the sequence of emanation does not actually seem to entail a fundamental ontological difference for Eckhart, but has at its core God's absolute being. ${ }^{86}$ As Schwartz aptly observes, the Eckhartian "God is simultaneously the most transcendent and most immanent entity." 87 In In Ioh. nn. 34-35, Eckhart highlights his view of John 1:1-2 as philosophically mirroring the tenet of Holy Trinity. ${ }^{88}$ Perhaps the fact that Ibn Gabirol's Fons vitae appears to coincide with notions present in the prologue of the Gospel of John on several central points might have stimulated Eckhart to draw support from it. ${ }^{89}$

83 See Brunner, "Maître Eckhart et Avicébron,” 140, 142.

84 See Flasch, Meister Eckhart: Philosopher of Christianity, 246, 259.

85 For Eckhart's equation of God and the world, see Flasch, Meister Eckhart: Philosopher of Christianity, 175, 189, 243-44. For a detailed discussion of the development of these four Aristotelian inquiries within Islamic and Jewish philosophy, see Altmann and Stern, Isaac Israeli, 13-23.

86 For Eckhart's “metaphysics of the verbum," see Flasch, Meister Eckhart: Philosopher of Christianity, 36-37, 70, 89-90, 117, 169, 177-81, 185-87, 244, 246.

87 Schwartz, "Meister Eckhart and Moses Maimonides," 399.

88 LW 3, 20-21, 28-30. Cf. In Ioh. nn. 38 [LW 3, 32-33], 45 [LW 3, 37.13-38.2], 54 [LW 3, 45.2-7]. See Flasch, Meister Eckhart: Philosopher of Christianity, 178, 201-2, 239.

89 In section 16 of chapter 3 of Fons vitae, for example, we read: "This is why the primary Creator is said to be present in all existing things, and without him nothing can exist" [et ideo dictum est quod factor primus est in omnibus quae sunt et nihil sine eo esse potest] (FV 3:16 [114.4-6]; my emphasis). This is quite reminiscent of the Vulgate's Latin translation of John 1:3, which reads: “Omnia per ipsum facta sunt et sine ipso factum est nihil.” See also FV 5:39 [327.15-17]. 


\section{Avicebron's Chain of Being and Jacob's Ontological Ladder}

Concluding their reference to Fons vitae 5:24, the editors of the LW call further attention to In Gen.II n. 209, ${ }^{90}$ since Eckhart explicitly invokes this specific Avicebronian paragraph there. This exegetical reference is particularly interesting considering the fact-based on Abraham ibn Ezra's fragmentary account-that Ibn Gabirol actually advanced a philosophical reading of Jacob's vision of the heavenly ladder. ${ }^{91}$ In this section, Eckhart offers a philosophical analysis of Jacob's ladder in Vg. Gen 28:1213. ${ }^{92}$ At the outset of his interpretation of this biblical depiction and prior to his mention of Fons vitae, he draws on chapter 10 of the second part of Maimonides's Guide of the Perplexed, using it as the main reference point for his entire exegetical discussion. ${ }^{93}$ Within a general metaphysical analysis of the number four, Maimonides then clarifies Jacob's dream of the heavenly ladder. The category of four is relevant for Maimonides's understanding of Jacob's vision, inasmuch as he assumes that four angels made use of the ladder, two ascending and two descending. According to Maimonides, the four angels on the ladder allegorically correspond to the four elements of the sublunar universe: fire and air match the two ascending angels, while water and earth match the two descending ones. ${ }^{94}$ The manner in which Eckhart goes on to explicate Maimonides's explanation of Jacob's ladder is quite surprising. He does not simply subscribe to Maimonides's specific alignment of the four angels to the four empirical elements, but perceives it as an ontological claim markedly wider in scope, reproducing the fourfold structure of the cosmos. ${ }^{95}$

90 LW 3, 39 n. 2.

91 See Schlanger, The Philosophy of Solomon Ibn Gabirol, 20. For further analysis of the Gabirolean exegesis of Genesis, see Julius Guttmann, "Zu Gabirols allegorischer Deutung der Erzählung vom Paradies," Monatsschrift für Geschichte und Wissenschaft des Judentums 80 (1936): 180-84; Sara Klein-Braslavy, “The Philosophical Exegesis,” in Hebrew Bible/Old Testament: The History of Its Interpretation, ed. Magne Sæbø (Göttingen: Vandenhoeck \& Ruprecht, 2000), vol. 1, part 2: 304-6.

92 "Vidit quoque in somnis scalam stantem super terram et cacumen eius tangens caelum et angelos dei ascendentes et descendentes per eam et dominum innixum scalae” (LW 1, 667.2-5).

93 LW 1, 677-79. For a comprehensive and insightful interpretation of Eckhart's usage of Maimonides’s exegesis of Jacob's ladder, see Schwartz, “To Thee Is Silence Praise," 256-65.

94 See Sara Klein-Braslavy, "Bible Commentary," in The Cambridge Companion to Maimonides, ed. Kenneth Seeskin (Cambridge: Cambridge University Press, 2005), 260-61; Schwartz, “To Thee Is Silence Praise,” 257; Gad Freudenthal, "Maimonides on the Scope of Metaphysics alias Ma'aseh Merkavah: The Evolution of His Views,” in Maimónides y su época, ed. Carlos del Valle, Santiago GarciaJalón, and Juan Pedro Monferrer (Madrid: Sociedad Estatal de Conmemoraciones Culturales, 2007), 224-30. Eckhart is alluding, of course, to this reading: LW 1, 678.14-15 ("quarto elementa mundi quattuor”), 681.13-683.11. For the other two instances in which Maimonides interprets Jacob's ladder in The Guide of the Perplexed, see The Guide of the Perplexed, trans. Shlomo Pines, 2 vols. (Chicago: University of Chicago Press, 1963), 1:12-13 [part 1, introduction], 1:41 [1:15] (henceforth Guide).

95 In Gen.II 209 [LW 1, 684.1-2]. 
This becomes apparent in Eckhart's recourse to Proclus's Elementatio theologica, by which he reframes the Maimonidean reading of Gen 28:12-13 in distinctly Neoplatonic terms. ${ }^{96}$ Drawing on proposition 20 of Elementatio theologica-which states that "beyond all bodies is the soul's essence, beyond all souls, the intellective principle; and beyond all intellective substances, the One" ${ }^{97}$-Eckhart makes Maimonides's Aristotelean explication of Jacob's ladder conform to Proclus's outlined structure of reality in its fourfold hierarchical structure of emanation: (1) the One, (2) the universal intellect, (3) the soul, and (4) the corporeal realm. ${ }^{98}$ The merging of Ibn Gabirol with Proclus's Elementatio theologica has a provocative edge, if one keeps in mind Albertus Magnus's critical treatment of Avicebronian philosophy specifically within the context of his commentary on this work in its Latin rendition as Liber de causis. ${ }^{99}$

At this point, seeking to reinforce his own Neoplatonic and dynamic take on the heavenly ladder, Eckhart proceeds to cite from what appears to be his favourite part of Fons vitae; namely, section 24 of chapter 5. This is the specific section through which he supports his reading of John 1:1-2 as well as that of Gen 1:1. Citing almost three entire paragraphs, constituting two successive answers from the magister (!), in which Ibn Gabirol provides a succinct account of his ontological Weltanschauung (301.16-302.7, 9-15), Eckhart brings his Neoplatonic view of Gen 28:12-13 to its conceptual peak. ${ }^{100}$

While one cannot simply ignore the central role of Maimonides here, it does appear that Eckhart adduces him particularly for his basic exegetical intuition, through which he is able to discern the ladder's basic symbolic meaning as signifying the fourfold order of reality. However, to address the question of what ultimately constitutes each of the respective ontological ranks, he takes an Avicebronian perspective. The three different layers of philosophical views on the structure of the universewhich, on the face of it, Eckhart seems to conflate ${ }^{101}$-might entail a certain hierarchical order: having Jewish Aristotelianism (Maimonides) as his starting point, then turning to its logical continuation in the form of pagan Neoplatonism (Proclus), and culminating in what Eckhart thought to be Christian Neoplatonism (Avicebron).

96 Cf. Schwartz, “To Thee Is Silence Praise,” 259.

97 Proclus, The Elements of Theology, trans. Eric R. Dodds, 2nd ed. (Oxford: Oxford University Press, 1971), 23.

98 For Eckhart's dynamic understanding of the ladder as a symbol of the fourfold structure of the universe, see Schwartz, “To Thee Is Silence Praise,” 258, 260.

99 Nevertheless, as McGinn observes, Eckhart's specific unifying approach seems to have become more prevalent in his time, with thinkers such as Berthold Moosburg (?-after 1361): McGinn, The Mystical Thought of Meister Eckhart, 173. Cf. Brunner, "Maître Eckhart et Avicébron," 139. On the possible impact that Proclus's Elementatio theologica could have exerted on Fons vitae, see Schlanger, The Philosophy of Solomon Ibn Gabirol, 68-71; McGinn, "Ibn Gabirol: The Sage among the Schoolmen,” 7980; Brunner, "Maître Eckhart et Avicébron,” 142-43, 145.

100 For an accurate account of this reference to Ibn Gabirol, see also Palazzo, "Eckhart's Islamic and Jewish Sources,” 278-79.

101 Schwartz lays out this insightful perspective: Schwartz, “To Thee Is Silence Praise,” 259. 


\section{Seeing God's Hidden Face through Avicebron's Negative Theology}

As McGinn hints, another, even more explicit conflation of Maimonides with Ibn Gabirol in Eckhart's thought finds its expression in his negative theological reading of Exod 33:23b ("faciem meam videre non poteris"). ${ }^{102}$ This time, however, Eckhart's exegesis takes its departure not from The Guide of the Perplexed, but rather from Fons vitae:

In Book 1, Chapter 4, of the Fountain of Life Avicebron asks, "Is there any way to understand the first essence?" His response is that "this is not impossible, but it is not possible in any way whatever. It is impossible to know the first of essences apart from the created things that come from it; it can be known from its works. [...] He adds that [full] knowledge of the essence of the First, that is, God's essence, is impossible, because it is above all things, because it is infinite, because it is not like the intellect, and because the First Essence and the intellect do not agree and have a mutual bond.” In Book 1, Chapter 58, Rabbi Moses says, “The sages agree that the sciences do not apprehend the Creator; only God himself can grasp his essence.” Nevertheless, Moses knew everything that we can know about him to the limit of our apprehension. What he knew no one before or after him knew, as Rabbi Moses says in the same chapter (In Ex. n. 281 [LW 2, 225.5226.7]). ${ }^{103}$

In spite of the fact that Eckhart appears to be following Maimonides's metaphysical illumination of Exod 33:23, he commences his interpretation by presenting the chief epistemological and ontological premises at the core of Ibn Gabirol's apophatic theology in its original interrogative form: that directly apprehending God's absolute transcendent being as the first essence (essentiae primae) is, strictly speaking, impossible. The sole possible way of knowing Him - that is, merely knowing that He existsis by means of mediation; namely, through His created works. ${ }^{104}$ Eckhart proceeds to bring forth the four reasons that Ibn Gabirol subsequently provides which completely rule out human soul's potential to conceive of God's primary essence: (1) God "is above all things"; ${ }^{105}$ (2) He is infinite; ${ }^{106}$ (3) God's purely unified being is dissimilar in every sense from the universal intellect and its dual structure compounded of matter and form, ${ }^{107}$ which is rather analogous to the human intellect; ${ }^{108}$ and finally,

102 McGinn, The Mystical Thought of Meister Eckhart, 173. For Eckhart's programmatic exegesis of the book of Exodus, see Flasch, Meister Eckhart: Philosopher of Christianity, 142-54.

103 I took this citation from the English translation by McGinn: Meister Eckhart: Teacher and Preacher, ed. and trans. Bernard McGinn (New York: Paulist Press, 1986), 129 (henceforth LWE).

104 FV 1:4 [6.16-22].

105 FL 64 [FV 1:5 (6.24)].

106 FV 1:5 [6.24].

107 See, for example, FV 1:7 [10.20]. For further analysis, see Pessin, Ibn Gabirol's Theology of Desire, 82-84.

108 FV 1:5 [7.1-7]. 
(4) the primary essence does not have any ontological point of commonality with the universal intellect. ${ }^{109}$ It is important to note that at the core of all these arguments lies Ibn Gabirol's hylomorphic hypothesis, from which a fundamental division emerges between the pure One and the twofold being consisting of universal matter and form.

Intending to reaffirm his Avicebronian reading, Eckhart cites excerpts from chapters $54^{110}$ and $59^{111}$ from the first part of The Guide of the Perplexed, which are broadly congruent with Ibn Gabirol's negative theology. ${ }^{112}$ The basic ideas Eckhart employs here are already, for the most part, present in Ibn Gabirol's thought: ${ }^{113}$ the human intellect's absolute incapability of apprehending God's essence, thereby restricting man's knowledge of God to His attributes of action and the mere fact of His existence. ${ }^{114}$ Maimonides's relevance for Eckhart's exegesis of Exod 33:23 actually appears to lie not so much in a tangible philosophical contribution, but rather in an exegetical one: drawing support for his negative theological understanding of Jewish Scripture. Interestingly, at the same time, Eckhart exploits two elements from Maimonides's explanations-Moses's exceptional knowledge of God and God's apprehension of Himself-to buttress his own affirmative theology, which, by supernatural means, permits the human intellect to access God's being. ${ }^{115}$ Thus, while Eckhart puts forward the tenets of Gabirolean apophatic theology in strict terms, he pinpoints the "weak spots" in the Maimonidean ones.

Ibn Gabirol's speculative philosophy also proves significant for Eckhart's initial reading of the analogous depiction of Vg. Exod 33:13b ("ostende mihi faciem tuam") in its peculiar Latin rendition, ${ }^{116}$ in which Moses asks God to reveal His face. Follow-

109 FV 1:5 [7.2-3]. Palazzo provides the most comprehensive interpretation of this passage: "Eckhart's Islamic and Jewish Sources," 280-81. Cf. also Schwartz, “To Thee Is Silence Praise," 178-79, and Udo Kern, “Gottes Sein ist mein Leben.” Philosophische Brocken bei Meister Eckhart (Berlin: De Gruyter, 2003), 231-32.

110 Guide 1:123 (given as chapter 53 in the Latin edition).

111 Guide 1:139 (given as chapter 58 in the Latin edition).

112 For a detailed and profound analysis of Eckhart's use of Maimonidean apophatic theology here, see Schwartz, “To Thee Is Silence Praise,” 177-79; Flasch, Meister Eckhart: Philosopher of Christianity, 247.

113 For a more thorough examination of Ibn Gabirol's apophatic theology, see Schlanger, The Philosophy of Solomon Ibn Gabirol, 98, 220-22; Pessin, Ibn Gabirol's Theology of Desire, 118-39. For Ibn Gabirol's negative theology, see, for example, FV 2:20 [61.3-8], 3:3 [78.24-79.1]: 3:5 [88.18-25], 3:6 [91.7-29], 3:7 [92.9-10], 3:8 [93.19-28], esp. 3:11 [103.21-104.17], 3:15 [109.22-27], 3:56 [204.13-205.7]. 114 This is the limited knowledge of God that Maimonides ascribes to Moses in the context of the passage cited from chapter 54 of book 1 of the Guide: "The answer to the two requests that He, may He be exalted, gave him consisted in His promising him to let him know all His attributes, making it known to him that they are His actions, and teaching him that His essence cannot be grasped as it really is" (Guide 1:123).

115 LW 2, 225.13-226.7. Cf. Kern, “Gottes Sein ist mein Leben,” 232-33; Schwartz, “To Thee Is Silence Praise," 179.

116 The original Hebrew reads: hodi'eni na' et derakhekha. 
ing citations from Augustine's On the Trinity and Confessions, he goes on to quote the concluding section of Fons vitae: ${ }^{117}$ "S: What will help attain this noble hope [sc. the avoidance of death and union with the origin of life]? T: To be separated first from sensible things, to be poured out in intelligible things by the mind, and to be completely suspended from the giver of goodness."118

In the cited passage, Ibn Gabirol-with an allusion to Ps 36:10-delineates his conception of man's aspiration to apprehend God in Neoplatonic terms: as the ascendance of the human soul to the transcendent Good and the source of life for the purpose of unification, thus triumphing over death and attaining salvation. This invocation of Fons vitae implies that Eckhart-similar to his understanding of Maimonides-ultimately construes Ibn Gabirol's metaphysics as resorting to cataphatic theology. As Palazzo concisely points out, this specific employment shares a thematic feature common to several of the other Eckhartian references to Avicebron: "The teaching on intellectual perfection is one of the main focuses of Eckhart's reading of the Fons vitae." 119 In his employment of Fons vitae, Eckhart, as Palazzo claims, "is inclined to emphasize [...] the existential dimension in the process of achieving intellectual perfection." 120

The aligning of Avicebronian and Maimonidean negative theology is, however, even more far-reaching. In fact, already in Eckhart's In Ex. n. 58, as part of a lengthy philosophical elucidation of one of the opening lines of the Song of the Sea (Vg. Exod 15:3b: "Omnipotens nomen eius"; YHWH iš milhamah YHWH šemo in the original Hebrew), he resorts to Ibn Gabirol and Maimonides. ${ }^{121}$ The discussion at hand revolves around his understanding of the Vulgate formulation "Omnipotens nomen eius" ("Almighty is his name”), which he explicates by recourse to thought patterns that are pivotal to negative theology. The main thread of his exegesis lies in the assumption that the omnipotence of God's name insinuates that His essence is inexpressible in terms of discursive thought. ${ }^{122}$ This, in turn, implies God's absolute transcendence and pure unity, which, strictly speaking, does not entail multiplicity in any form:

The distinction which the term "all" implies is indeed guilt, fault, and defect in existence and unity. Everything that exists is either above all and above number, or is numbered among all things. But above all and outside number there is only the One. No difference at all is or can be in the One, but "All difference is below the One," as it says in the Fountain of Life, Book

117 Eckhart actually states that the source of this quotation is book 3 of Fons vitae. Cf. Palazzo, "Eckhart's Islamic and Jewish Sources," 273 n. 51.

118 FL 261 (FV 5:43 [338.22-27]).

119 Palazzo, "Eckhart's Islamic and Jewish Sources," 280.

120 Palazzo, 280. Cf. Schwartz, "Meister Eckhart and Moses Maimonides," 409-12; Brunner, "Maître Eckhart et Avicébron,” 150-51.

121 Brunner, 143.

122 See, for example, In Ex. n. 35 [LW 2, 41.6-15, 42.1-5] and 57 [LW 2, 63.7-13]. For a detailed and profound analysis of the influence of Maimonides on Eckhart in relation to speaking or naming God, see Schwartz, "To Thee Is Silence Praise," 201-37. 


\begin{abstract}
5. "That is truly one in which there is no number," as Boethius says. And Rabbi Moses, as mentioned above, says that God is one "in all ways and according to every respect," so that any "multiplicity either in intellect or in reality," is not found in him. Anyone who beholds [the number] two or who beholds distinction does not behold God, for God is one, outside and beyond number, and is not counted with anything (In Ex. n. 58 [LW 2, 64.10-65.6]). ${ }^{123}$
\end{abstract}

In this citation, Eckhart addresses the question of whether ascribing positive attributes to God is merely a medium through which the human intellect is able to construe God's entity in terms that are more concrete. ${ }^{124}$ Eckhart's response is decisive: God's essence is inconceivable by means of His primary determinations-such as wisdom, power, and goodness ${ }^{125}$-for His pure unified being transcends all these conceptual differentiations. It is at this thematic juncture that Eckhart invokes Ibn Gabirol, Maimonides, and Boethius in order to strengthen his negative theological viewpoint. As in In Ioh. n. 389, ${ }^{126}$ here too, Eckhart refers to the Gabirolean premise from section 23 of Fons vitae's chapter 5 [300.16-17], which situates the category of "difference [...] below the One" ("differentia non est nisi sub uno"). ${ }^{127}$ He then proceeds to quote chapter 51 of the first book of The Guide of the Perplexed, in which Maimonides claims that in God's strict oneness, no "multiplicity either in the thing as it is outside of the mind or as it is in the mind" can be present. ${ }^{128}$ Eckhart's correlation of Ibn Gabirol and Maimonides, both in general and in this specific passage, caught the attention of Bernard McGinn. In his monograph on Meister Eckhart entitled The Mystical Thought: The Man from Whom God Hid Nothing, he states that "Eckhart cited Gabirol in his Latin works mostly for the Jewish philosopher's emphasis on God as Absolute Unity," while stressing that "it is interesting to see him combining Maimonides and Gabirol with the Christian witness of Boethius to proof-text his teaching on God's oneness." 129

A further examination of Eckhart's own line of reasoning-laid out prior to his invocation of these three authoritative sources-prompts the conjecture that it echoes distinct Gabirolean views. Even the editors of the LW have partially recognised this fact, inasmuch as they suggest that Eckhart's assertion regarding the numerical order

123 LWE 63 (emphasis in original). Cf. In Ex. n. 90 ("In uno autem non est maius aut minus. Omnis enim 'differentia sub uno' est, ut supra, dictum est”). For further analysis of this Eckhartian theme, see Mojsisch, Meister Eckhart: Analogy, Univocity and Unity, 98-99; Flasch, Meister Eckhart: Philosopher of Christianity, 138-39.

124 In Ex. n. 58 [LW 2, 63.14-64.1].

125 For a detailed account of Eckhart's primary determinations (Erstbestimmungen), see Flasch, Meister Eckhart: Philosopher of Christianity, 77-85.

126 Cf. LW 2, 64 n. 3.

127 Brunner, "Maître Eckhart et Avicébron,” 142-43.

128 Guide 1:113.

129 McGinn, The Mystical Thought of Meister Eckhart, 172-73. Cf. Flasch, Meister Eckhart: Philosopher of Christianity, 200-202, 244-46, 268-69, 276. 
of being falling under the ultimate One stems from Fons vitae 4:13 (239.12-17). By comparing both passages, their similarities come effectively to the fore:

Creatures, by the fact that they are from the One And it seems to me that the substances that are but below the One, necessarily fall into number, ordered below the intelligence are ordered beplurality, distinction, guilt, and fault, a condition cause of the order of numbers, since they fall by which they are numbered among all the things under one. [...] In general, when you consider all that are. That which commits an offense in the the things that exist, you will find them ordered One and against the One incurs the guilt of dis- and constituted according to the nature of numtinction and falls into the all [et per creaturas, ber, and you will find all things falling under the ubi necessario hoc ipso quod ab uno quidem, form of the intelligence, which is unity, for the reased sub uno sunt, incidunt in numerum multitu- son that every number falls under one. Because of dinem et distinctionem et reatum seu maculam, this, the form of the intelligence and its essence quo inter omnia numerantur. Quod enim in uno gather everything and comprehend everything et unum offendit cadens $a b$ uno, incidit reatum [et omnimo cum consideraueris omnia ea quae distinctionis et cadit inter omnia] (In Ex. n. 58 sunt, invenies ea ordinata et constituta secundum [LW 2, 64.3-7]; my emphasis). ${ }^{130}$ naturam numeri, et invenies omnia cadentia infra formam intelligentiae, quae est unitas, ideo quia omnis numerus cadit sub uno; et propter hoc forma intelligentiae et eius essentia est collectiva omnis rei et comprehendens omne] (FV 4:13 [239.12-17]; my emphasis). ${ }^{131}$

In fact, Eckhart's identification of the category of the true One as being above the concept of number is not what renders this parallel so special. ${ }^{132}$ Rather, it is the logical development of this view, which claims that created reality rests on a fixed numerical structure. Similarly, Eckhart's subsequent exegetical analysis of the concept of omnia from Vg. Jas 2:10 133 appears to be illuminated in terms of this Avicebronian division, differentiating between a purely unified totality that transcends number altogether and a totality confined to numerical order: "Everything that exists is either above all and above number, or is numbered among all things. But above all and outside number there is only the One." 134

130 LWE 63.

131 FL 204.

132 Cf. In Eccli. n. 149 [LW 2, 487.2-5].

133 "Quicumque autem totam legem servaverit offendat autem in uno factus est omnium reus" (my emphasis).

134 LW 2, 64.10-11 [LWE 63]. Another thematic juncture in Eckhart's Commentary on Exodus, in which he philosophically expounds on one of the divine names, is In Ex. n. 18. In this section, Eckhart seemingly applies the four Aristotelian forms of inquiries from book 2 of An. post. to God's revealed name in Vg. Exod 3:14a ("Ego sum qui sum"). However, as the editors of the LW point out (LW 2, 24 n. 2), Eckhart-who sees a direct conceptual link between this biblical verse and John 1:1-3 (In Ex. n. 15 [LW 2, 20.11-12], 16 [LW 2, 22.7-9])-applies these questions to God as the absolute being in a similar fashion to Fons vitae 5:24. Like Ibn Gabirol, he too essentially asserts that it only makes sense to apply the question "whether" to God: "But in God where 'that-it-is' is the 'what-it-is' itself, a fitting answer to someone asking who or what is God is 'God is,' for God's existence is his 'what-it- 


\section{The Absolute Transcendence of God's Universal Form}

Eckhart's invocation of Avicebron in section 9 of his commentary on the Wisdom of Sirach is also revealing. In his speculative reading of Sir 24:23, he exhibits his particular appreciation of Ibn Gabirol's insight into concepts relating to the transcendent realm. Here, Eckhart brings up Avicebron within a context that is pivotal to his understanding of what constitutes Godly wisdom:

To the realm of the purity of substance belongs the meaning of the [personal] pronoun "I." This is the initial thing which is sought after in the beloved; that is, purity without any admixture. This [purity] truly pertains to Divine wisdom. For this reason, the author of Fons vitae contends the following about God, the transcendent and Holy, in book 5: "[He is the] substance constituting the existence of all forms; the perfect wisdom and purest illumination" (In Eccli. n. 9 [LW 2, 238.7-12]; my translation).

As Joseph Koch notes in the critical edition of the LW, in the original passage in Fons vitae 5:22 [298.17-21], Ibn Gabirol is in fact not depicting God, but rather the universal form. ${ }^{135}$ In spite of this blatant misrepresentation of Ibn Gabirol's philosophical intent, it assists us in unearthing Eckhart's programmatic picture of Avicebron: probably regarding him as neither a Jewish nor a Muslim thinker, but as a Christian Platonist writing in Arabic. The identification of Avicebron's Neoplatonic conceptualisation of wisdom as the totality of forms with his own notion of intellect entailing the world of ideas ${ }^{136}$ could have enticed Eckhart to misconstrue Ibn Gabirol as a Christian Platonist positing a consubstantial worldview, which puts the intellect as the divine Word and wisdom on the same ontological level as God. ${ }^{137}$ Following Brunner, ${ }^{138}$ Palazzo is right to suggest that "the very combination of the notions of

\footnotetext{
is.' He says, 'I am who am”' (LW 2, 24.5-7 [LWE 47]). Drawing on these Aristotelian types of questions, Ibn Gabirol prompts the conclusion that God's mere existence is the only fact that human knowledge can infer regarding Him (FV 5:24 [301.18-302.1]). For Schwartz's extensive treatment of Eckhart's drawing on the Maimonidean explication of the divine name in Exod 3:14, see Schwartz, "To Thee Is Silence Praise," 229-37; Schwartz, "Meister Eckhart and Moses Maimonides," 401-8. Cf. also Brunner, "Maitre Eckhart et Avicébron," 144. On Eckhart's equation of God with the category of being, see Mojsisch, Meister Eckhart: Analogy, Univocity and Unity, 51-65; Roberto Vinco, "Meister Eckhart's Nonstandard Natural Theology," Neue Zeitschrift für Systematische Theologie und Religionsphilosophie 58, no. 4 (2016): 485-89; Flasch, Meister Eckhart: Philosopher of Christianity, 138, 143-51.

135 LW 2, 238 n. 6. Cf. Brunner, "Maître Eckhart et Avicébron,” 144, and Palazzo, "Eckhart’s Islamic and Jewish Sources," 275.

136 See, for example, In Eccli. n. 10 [LW 2, 240.3-7].

137 Cf. Brunner, "Maître Eckhart et Avicébron," 144-45.

138 Brunner, 144.
} 
purity and wisdom in the passages of the Fons vitae would have led Eckhart to single out and apply them, in contrast with their original meaning, to God.”139

While this assertion is in itself true, one must also account for the wider framework in which Eckhart puts this Gabirolean notion to use. The specific paragraph takes its thematic and exegetical departure from John 1:1, to which Eckhart alludes for the sake of underpinning the human aspiration to grasp God the Father as the ultimate origin. ${ }^{140}$ Here, Eckhart explicates the opening verse of the prologue of the Gospel of John through the complementary relationship between thought and its discursive expression by means of uttered words. ${ }^{141}$ Eckhart also reads this Avicebronian passage in analogous terms: as a creative divine wisdom, which is purely one and from which the noetic world emanates. He seemingly conflates the universal form with the universal intellect as the totality of forms ${ }^{142}$ and then moves on to equate the universal intellect with God. Examining subsequent sections from chapter 5 of Fons vitae, one actually encounters similar depictions of the universal intellect. In Fons vitae 5:30, for example, Ibn Gabirol portrays the universal intellect as the divine verbum, which he identifies with the noetic light which establishes forms. ${ }^{143}$ At the outset of the concluding section of Fons vitae, Ibn Gabirol likens God's divine creation to the utterance of a word. ${ }^{144}$ Furthermore, his distinct tendency to portray the universal intellect in analogous terms to his description of God in chapter 5 may also have facilitated Eckhart's misinterpretation of Fons vitae 5:22 [298.17-21]. In chapters 38 and 39 of Fons vitae, Ibn Gabirol asserts that the divine Will is indescribable, ${ }^{145}$ above the categories of movement and time, ${ }^{146}$ omnipresent, and that "nothing exists apart from it inasmuch as the existence and constitution of all things depends on it."147

139 Palazzo, "Eckhart's Islamic and Jewish Sources,” 275.

140 Eckhart proceeds to cite John 14:8: "Domine, ostende nobis Patrem, et sufficit nobis."

141 LW 2, 237.11: "Verbum enim ad notitiam et intellectum pertinent." Cf. In Eccli. n. 12 [LW 2, 241.8242.8].

142 See, for example, FV 3:32 [153.1-4]. For the Gabirolean conflation of the divine Will with the universal form, see Schlanger, The Philosophy of Solomon Ibn Gabirol, 195-97.

143 313.15-17. Cf. FV 4:20 [254.19-24], 3:53 [196.24-197.15].

144 For further analysis of this Gabirolean depiction, see Schlanger, The Philosophy of Solomon Ibn Gabirol, 32, 48, 53, 230-32; McGinn, "Ibn Gabirol: The Sage among the Schoolmen," 90-92.

145 FV 5:38 [326.3].

146 FV 5:39 [328.11-13]; also FV 3:57 [205.23-206.5]. See Schlanger, The Philosophy of Solomon Ibn Gabirol, 166.

147 FV 5:39 [327.14-17]. For Ibn Gabirol's portrayals of the divine Will in transcendent terms, see Schlanger, The Philosophy of Solomon Ibn Gabirol, 172, 223-28. 


\section{Platonising Avicebronian Hylomorphism}

One of the unifying features of Eckhart's employment of Fons vitae in his Commentary on the Gospel of John is Ibn Gabirol's universal hylomorphism. In his reading of three different verses-Vg. John 1:48, 8:34, and 14:8-this Avicebronian doctrine, which claims that all levels of the cosmos consist of the universal principles of matter and form, is brought to the fore.

Aiming to establish that the divine omniscience and providence allegedly purported in Vg. John 1:48 ${ }^{148}$ match up with accepted philosophical tenets, ${ }^{149}$ Eckhart turns to draw support from this Avicebronian worldview. The primary notion that Eckhart has in mind here appears to be a Platonic one; namely, the demiurge's goodness as the impetus for his creation of the cosmos (Ti. 29e1). ${ }^{150}$ Through Plato's cosmologic concept of the demiurge, Eckhart is able to substantiate one of his initial assertions regarding Vg. John 1:48: by virtue of his artistic skill, the artificer sees the piece of art prior to his production of it. ${ }^{151}$ After two citations from Avicenna, ${ }^{152}$ he moves on to quote two interrelated passages from chapter 3 of Fons vitae, towards which he-as Palazzo notes-particularly gravitated: ${ }^{153}$

Hence, it is necessary that form give itself and its own form to what is prepared to receive it. This is a more evident sign that form proceeded from the first maker and is obedient to him, because it is compelled in its own nature to give itself and to confer its own form, when it finds matter receptive of it. Moreover, because there was a first making and, similarly, a first action, it was necessary that this making and this action penetrated through everything until there was a lack of something able to receive them (FV 3:14 [108.19-20, 108.23-109.3]). ${ }^{154}$

It might not immediately stand to reason why Eckhart continues his citation of Avicenna's Metaphysics with these specific passages from chapter 3 of Fons vitae. Eckhart seems to place both the Avicennian and the Avicebronian descriptions within

148 "Priusquam te Philippus vocaret cum esses sub ficu vidi te."

149 In Ioh. n. 251 [LW 3, 209.11-12].

150 In Ioh. n. 262 [LW 3, 217.6-7].

151 In Ioh. n. 255 [LW 3, 212.3-4]. For further analysis, see Flasch, Meister Eckhart: Philosopher of Christianity, 182-83.

152 For Eckhart's linkage of Avicenna and Avicebron in the context of the passage at hand, see Palazzo, “Eckhart’s Islamic and Jewish Sources,” 276. Cf. Yossef Schwartz, "Thirteenth Century Hebrew Psychological Discussion: The Role of Latin Sources in the Formation of Hebrew Aristotelianism," in The Letter Before the Spirit: The Importance of Text Editions for the Study of the Reception of Aristotle, ed. Aafke M.I. van Oppenraay and Resianne Fontaine (Leiden: Brill, 2012), 175-78, 190 ("As claimed above, a close reading of Gundissalinus' Tractatus de anima reveals a unique Latin mixture of Avicenna with Gabirol, creating a form of 'Gabirolian Avicennism.' The 'Jewish,' Gabirolian part of this synthesis does not disturb the early translator of Tractatus de anima but is absolutely neglected by Gershom and Hillel, who systematically ignore the Gabirolian themes and terminology").

153 Schwartz, "Thirteenth Century Hebrew Psychological Discussion," 276 n. 60.

154 FL 128. 
the cosmologic account of Plato's Timaeus. ${ }^{155}$ Both philosophers advance a similar Neoplatonic outlook towards God and His creation: in His overflowing goodness and pure actuality as the first cause, God brings the world into existence and makes it comply with His divine will. ${ }^{156}$ While Eckhart, like Avicenna, stresses the goodness of creation resulting from God's own overflowing goodness, he analogously shows through Avicebron how the universal form, by directly imitating God's pure active power, enforces itself upon its receptive counterpart, the materia spiritualis. ${ }^{157}$ The closing remark of this paragraph also provides a further indication as to what Eckhart has in mind when quoting Avicebron here: "Doctores etiam dicunt quod angeli superiores illuminant inferiores naturaliter de omnibus quae noverunt." 158 The overlapping characteristic between Avicebronian and Christian teaching is that God endows His pure intelligible substances (universal form/high angels) with knowledge, which they then convey and apply onwards to lower ontological realms (matter/lower angels). ${ }^{159}$

Eckhart's exegetical observations regarding Vg. John 8:34b (“omnis qui facit peccatum, servus est peccati”) in In Ioh. n. 463 also centre on Avicebronian hylomorphism. In fact, it serves as an important philosophical reference point for his entire reading of this verse. Through Ibn Gabirol's Fons vitae 3:14, Eckhart substantiates

155 It is not surprising that Eckhart links Avicebron to cosmologic notions from Platonic philosophy, since Plato is the only philosopher referred to in Fons vitae (FV 4:8, 5:17). For a discussion of Gabirolean hylomorphism seen from the perspective of Platonic metaphysics, see Pessin, Ibn Gabirol's Theology of Desire, 165-67; McGinn, "Ibn Gabirol: The Sage among the Schoolmen," 89-90.

156 Cf. Palazzo's concise interpretation of this link made by Eckhart in "Eckhart's Islamic and Jewish Sources," 276: "While addressing the prophetical flow from God in the Commentary on the Gospel of John, Eckhart connects Avicenna's Metaphysics Book 8 Chapter 6 (which, as said, describes the Necessary Existent's ability to overflow and produce reality) with the Fons vitae text which argues that it befits form to communicate itself to matter, whenever the latter is apt to receive the former, and that in its process of self-communication form obeys the First Maker, Who is the originator of the universal flow of form” (emphasis in original). Cf. Brunner, "Maître Eckhart et Avicébron,” 147.

157 For a detailed analysis of this topic in Ibn Gabirol's theory of creation, see Schlanger, The Philosophy of Solomon Ibn Gabirol, 161-64, 166; McGinn, "Ibn Gabirol: The Sage among the Schoolmen," 84-85.

158 In Ioh. n. 263 [LW 3, 218.11-12]. Cf. the parallel passage in In Gen.II 146 [LW 1, 616.1-3]. Here, Eckhart describes the higher realm's contact with the lower realm in terms of love. Interestingly, Ibn Gabirol explains the relationship between God's creative activity, mediated by form in shaping passive matter, in quite similar terms in FV 3:13 [106.13-17]: "As to the nature of this activity, it is one entity endowing another with its own form, when each of them lends itself to this. As to how, it is by combining, either without or with an intermediary; either with alteration and decrease of the active form or on the contrary with no decrease of the active quality; either by the timeless impress of the active potency on the receptive entity, or by thought and imagination, as by something loved on the one who loves" (FL 100). The idea of this allusion to the Christian teachers in In Ioh. n. 263 also aligns well with Eckhart's initial citation of Avicenna relating to the angels' noetic communication with the inferior human souls (In Ioh. n. 262 [217.7-15]). For further analysis of Eckhart's use of Avicenna, see Palazzo, "Eckhart's Islamic and Jewish Sources," 257-71 (esp. 264).

159 Cf. Brunner, "Maître Eckhart et Avicébron," 145-46. 
two of his four clarifications of John 8:34b. He explicates this apparent moral notion that a person who commits a sin becomes its servant in Aristotelian terms, ${ }^{160}$ as the precept that each agent brings about that which ontologically matches itself ("cum omne agens agat sibi simile"). ${ }^{161}$ It is within this framework that Eckhart lays out the Avicebronian viewpoint, citing the exact same passages as in his reading of Vg. John 1:48. To this end, Eckhart insinuates that the principle of action is the universal form, imprinting its qualities on its receptive counterpart of universal matter. It is tempting to equate the sinful act with the mergence of form with matter, but that would be to miss Eckhart's philosophical point. His claim seems to be more basic. Taking its cue from God's transcendent activity, form endows its own nature on passive matter. The ontological symmetry is not so much related to the substrate of matter, but rather to form's articulation of its own essence. ${ }^{162}$ Earlier, Eckhart expresses this idea in conjuncture with Exod 3:14, arguing that God's modus operandi, by virtue of Him being being itself, consists of calling things into being. ${ }^{163}$ Proceeding to quote-as in his In Ioh. n. 263-Ibn Gabirol's subsequent depiction of God's creative productivity mediated by the universal form (108.25-109.3), Eckhart may also have been indicating that he has the same scheme in mind here: God's noetic being establishing the universe through the universal form, which reproduces His creative activity within a lower ontological realm. ${ }^{164}$ On examining the next paragraph (464), one finds further reinforcement for this assessment, inasmuch as Eckhart speaks of the Gabirolean concept of the universal form as God's mediator within the natural realm between activity (form) and passivity (matter) ("mediatio inter agens et patiens"). ${ }^{165}$

Again, referring to one of the above citations from Fons vitae 3:14, ${ }^{166}$ Eckhart attempts to show that the motif of servitude in Vg. John 8:34b implies a further metaphysical idea; that is, that the activity of each object serves its corresponding form by predisposing matter for its exhaustive absorption therein. ${ }^{167}$ Similar to his interpretation of Vg. John 1:48, instead of stressing the ontological symmetry between universal matter and form lying at the core of Avicebronian hylomorphism, Eckhart rather chooses to accentuate the clear ontological priority of creative form over pas-

160 See LW 3, 396 n. 1.

161 In Ioh. n. 463 [LW 3, 396.5].

162 Palazzo, “Eckhart's Islamic and Jewish Sources,” 276.

163 In Ioh. n. 463 [LW 3, 396.5-7].

164 For an elucidation of the participation of form in divine creation, see Schlanger, The Philosophy of Solomon Ibn Gabirol, 239-42. See, for example, 3:13 [106.17-107.9].

165 In Ioh. n. 464 [LW 3, 397.1-3].

166 108.25-26: "Forma [...] compellitur in natura sua ad dandum se et ad conferendum formam suam."

167 In Ioh. n. 467 [LW 3, 399.6-10]. Cf. Palazzo's succinct description of Eckhart's specific usage of Fons vitae here, in "Eckhart's Islamic and Jewish Sources," 276 n. 60: "Furthermore, Avicebron['s] text is quoted to make it clear that operation predisposes matter not only for form, but also for whatever is connected or proper to form.” 
sive matter that it posits. Eckhart's strong metaphysical reading of Vg. John 8:34b overshadows the literal ethical meaning of the verse to such an extent that their link to one another becomes blurred. ${ }^{168}$

The subsequent reference to Avicebron's universal hylomorphism in Eckhart's Commentary on the Gospel of John takes place in his reading of Vg. John 14:8 ("Domine, ostende nobis Patrem, et sufficit nobis"). Already in In Eccli. n. 9, we saw how Eckhart adduces what he perceived to be Avicebron's transcendent concept of God within an exegetical framework, in which the God the Father of Vg. John 14:8, understood as the principium sine principio, occupies a significant role. ${ }^{169}$ In In Ioh. n. 554, Eckhart analyses Vg. John 14:8 along similar lines, inasmuch as he attempts therein to throw light on different aspects of the transcendent oneness of God the Father. The one chief difference is that Eckhart does not directly refer to Avicebron's view of God, but rather to the superiority of form being a unifying principle over the passive and diversified matter. Eckhart inserts this Avicebronian viewpoint into his eighth reason, through which he accounts for the notion of God as the One. The general claim Eckhart advances is that "form and nature avoids and [...] detests matter." fect, he establishes a worldview of God being the absolute One as opposed to matter being pure multitude. Eckhart supports this philosophical perspective by referring to no less than three excerpts from Fons vitae: "Therefore, he says, 'Show us' the One, 'and it is enough for us.' The One is opposed to matter, in that it is many and evil, or nothing, as said above. Hence the author of the Fountain of Life in 2.9 and 10 and 3.4 denies that any bodies composed of matter have activity, but [says] they are only passive due to matter." 171 A cursory examination of the three passages to which Eckhart made recourse hints at the fact that at their core lies the sharp ontological contrast between God's pure actualism, conferred on the universal form, and the passive substrate of matter. It would thus appear that Eckhart, when drawing on these examples from Fons vitae, does not merely have Avicebron's precept concerning the passivity of matter in mind, but also the conceptual framework in which Ibn Gabirol advanced it. Against this backdrop, one can better observe how Eckhart's overall programmatic presentation here, which attempts to prove that God is the transcendent unity, corresponds to Gabirolean philosophy. ${ }^{172}$

168 On Eckhart's "philosophic allegorism” in his LW, see Schwartz, "Meister Eckhart and Moses Maimonides," 398.

169 LW 3, 237.11-238.2.

170 In Ioh. n. 551 [LW 3, 481.5-6] (FLW 183).

171 In Ioh. n. 554 [LW 3, 483.12-484.2] (FLW 184). Cf. Flasch, Meister Eckhart: Philosopher of Christianity, 181-182.

172 The section from Fons vitae 2:9 that Eckhart probably has in mind is 40.6-27: the view that Ibn Gabirol outlines here is of God's creative productivity, mediated through the active rational substances, imposed on the passive and receptive substrate of matter. Zimmermann and Sturlese offer 40.610: LW 3, 484 n. 1. The image from Fons vitae 2:9 that Eckhart draws upon is 40.6-27. As Zimmermann and Sturlese suggest, the specific section from the subsequent chapter in Fons vitae 2:10 from which Eckhart draws support is 41.11-16. In this passage, Ibn Gabirol opposes passive matter that has been 
By adducing this textual evidence from Fons vitae, Eckhart appears to want to actually weaken the sweeping thrust of the claims raised by Avicebronian hylomorphism. Instead of emphasising the exceptional ontological status of universal matter in Fons vitae-which Ibn Gabirol conceptualises as a basic noetic principle intrinsic to all of created reality and as even having priority over form ${ }^{173}$-Eckhart chooses to firmly relegate it to a secondary position. From this perspective, Eckhart can proceed to establish a baffling connection between Avicebron and Thomas Aquinas, as the latter also denies the possibility of matter being active ("Videtur quod nullum corpus sit activum"): "On this see Thomas in the [Summa of Theology], Ia, q. 115, a. 1." ${ }^{174}$ As is known, Aquinas, in light of his incorporeal conception of angels, systematically grapples specifically with the radical assertions of Avicebronian hylomorphism in four subsequent chapters (5-8) of his De substantiis separatis seu de angelorum natura. $^{175}$

\section{Summary}

This study maps Meister Eckhart's various explicit and implicit references to Avicebron's Fons vitae. What emerges from these invocations is an unusual image of Ibn Gabirol. Eckhart gives the eleventh-century Andalusian Jewish philosopher a significant position within his Christian body of thought, unmatched by most of his nonChristian sources of inspiration from the Middle Ages. Unlike other central non-Christian authorities cited by Eckhart, such as Rabbi Moyses (Maimonides) and the heidenischer meister (Avicenna), the ambiguity attached to the religious affiliation of the Avicebronian worldview appears to have actually contributed to its adoption. Eckhart, not entirely sure as to Avicebron's religious affiliation, could not only approach his innovative philosophy in a more objective way, but could also exploit it more flexibly for his own specific Christocentric interests.

Eckhart does not single out a specific theme from Fons vitae, but rather seems to endorse the outlook that Gabirolean thought provides. His fascination with Fons vitae centres on a wide array of topics covering the main ideas of Gabirolean philosophy. Aside from Ibn Gabirol's hylomorphism, Eckhart also draws on his notions

set in motion to God as the ultimate source of movement from which all of reality overflows. The editors of the critical edition specifically refer to 83.1-6. See LW 3, 484 n. 1 and cf. FV 1:14. The third section from Fons vitae 3:4 to which Eckhart may have wished to allude is 82.9-83.20. In these paragraphs, Ibn Gabirol depicts God as being the transcendent artificer of the universe, whose pure creative activity requires an intermediary substance in shaping passive matter. For further analysis, see Schlanger, The Philosophy of Solomon Ibn Gabirol, 132.

173 For matter's priority over form, see McGinn, "Ibn Gabirol: The Sage among the Schoolmen," 8687; Schlanger, The Philosophy of Solomon Ibn Gabirol, 181-82.

174 In Ioh. n. 554 [LW 3, 484.2-3] (LWE 184).

175 For a more detailed analysis of this correlation, see Brunner, "Maître Eckhart et Avicébron," 148. 
of divine creation, the intellectual ascent of the human intellect to the noetic realm, God's transcendent unity, negative theology, and the fourfold ordo essendi. Our survey has made it clear that in fact, it was not chiefly Fons vitae's well-known doctrine of universal hylomorphism that resonated with Eckhart's philosophy, but rather its outlined Einheitsmetaphysik, which conceptualises God as well as His creation through the determination of Oneness. The Gabirolean formulation that the Two follows from the One also does not lure him into thinking otherwise, for Eckhart knows that the category of the Two, denoting universal matter and form, is merely a construct to make Avicebronian hylomorphism more comprehensible. Strictly speaking, form and matter can only exist in their interdependent unity within the universal intellect.

At the same time, Eckhart seems to approach Fons vitae in a programmatic manner. This study has pointed to two of the inclinations underlying Eckhart's understanding of Avicebron: (1) Eckhart is reluctant to take Ibn Gabirol's radical hylomorphism at face value. Rather, he attempts to weaken the pivotal role of the Avicebronian Materialprinzip by decisively relegating it to the secondary status of a substrate for the creative productivity of form. (2) Although Eckhart was familiar with Ibn Gabirol's negative theology, he appears to want to conflate God with the universal form-as evidenced by his reading of Fons vitae 5:22 and his general presentation of Gabirolean hylomorphism-equating the universal form with God by virtue of its transcendence, unity, and creative power.

In Eckhart's reading of Fons vitae, the fifth chapter gains centre stage. The reason for this emphasis, as I have argued, lies in the fact that it harmonises well with Christian theological patterns of thought in general and with Eckhart's metaphysics of the verbum in particular. While it is certainly possible that Eckhart supposed Avicebron to be a Christian, I maintain that it was not this feature that attracted him to his universal philosophy, but rather the speculative thrust of his innovative metaphysics of the One. By incorporating such a unique philosophical voice as Ibn Gabirol into his thought, Eckhart could better account for the speculative elements intrinsic to the Christian faith and thus present them in a universal light. Given the scrutinising critique of Fons vitae levelled by the most celebrated Dominicans, Albertus Magnus and Thomas Aquinas, Eckhart's broad adoption of Avicebronian thought in his Christian philosophy stands out as being a rather subversive move. Inserting such a controversial philosophical source into his Christian philosophy must also factor in what Kurt Flasch assesses as Eckhart's “divergence from the traditional path of common scholasticism and his explicit polemical position against it." "176 Yet it would seem that precisely this subversiveness is that which renders Eckhart's Christian philosophy so appealing and worth exploring. 


\section{Bibliography}

Albertus Magnus. Buch über die Ursachen und den Hervorgang von allem aus der ersten Ursache: Liber de causis et processu universitatis a prima causa. Edited and translated by Henryk Anzulewicz, Maria Burger, Silvia Donati, Ruth Meyer, and Hannes Möhle. Hamburg: Felix Meiner Verlag, 2006.

Aristotle. Posterior Analytics. Topica. Translated by Hugh Tredennick and E.S. Forster. Cambridge, MA: Harvard University Press, 1960.

Augustine. On the Trinity: Books 8-15. Edited by Gareth B. Matthews. Translated by Stephen McKenna. Cambridge: Cambridge University Press, 2002.

Augustine. St. Augustine's Confessions in Two Volumes. Translated by William Watts. London: William Heinemann; Cambridge, MA: Harvard University Press, 1912.

Beccarisi, Alessandra. "Zwischen Averroes, Avicenna und Avicebron. Meister Eckhart und die Noetik im Islam und Judentum." In Meister Eckhart - interreligiös, edited by Christine Büchner, Markus Enders, and Dietmar Mieth, 223-40. Stuttgart: Kohlhammer, 2016.

Brunner, Fernand. "Maître Eckhart et Avicébron." In Lectionum Varietates. Hommage à Paul Vignaux (1904-1987), edited by Jean Jolivet, Zenon Kaluza, and Alain de Libera, 133-54. Paris: Vrin, 1991.

Meister Eckhart. Die deutschen Werke. Edited by Josef Quint and Georg Steer. 5 vols. Stuttgart: Kohlhammer, 1936-2016.

Meister Eckhart. Die lateinischen Werke. Edited by Konrad Weiss, Loris Sturlese, Albert Zimmermann, Joseph Koch, Heribert Fischer, Bruno Decker, Ernst Benz, Karl Christ, Bernhard Geyer, and Erich Seeberg. 5 vols. Stuttgart: Kohlhammer, 1936-.

Meister Eckhart. Meister Eckhart: Teacher and Preacher. Edited and translated by Bernard McGinn. New York: Paulist Press, 1986.

Meister Eckhart. Meister Eckhart: The Essential Sermons, Commentaries, Treatises, and Defense. Translated by Edmund Colledge and Bernard McGinn. New York: Paulist Press, 1981.

Meister Eckhart. Meister Eckhart: Werke II. Edited by Niklaus Largier. Translated by Josef Quint. Frankfurt am Main: Deutscher Klassiker Verlag, 1993.

Flasch, Kurt. Meister Eckhart. Die Geburt der "Deutschen Mystik" aus dem Geist der arabischen Philosophie. 2nd ed. Munich: Beck, 2008.

Flasch, Kurt. Meister Eckhart: Philosopher of Christianity. Translated by Anne Schindel and Aaron Vanides. New Haven: Yale University Press, 2015.

Freudenthal, Gad. "Maimonides on the Scope of Metaphysics alias Ma'aseh Merkavah: The Evolution of His Views." In Maimónides y su época, edited by Carlos del Valle, Santiago Garcia-Jalón, and Juan Pedro Monferrer, 221-30. Madrid: Sociedad Estatal de Conmemoraciones Culturales, 2007.

Ibn Gabirol, Solomon. Avencebrolis (Ibn Gabirol) Fons Vitae, ex Arabico in Latinum Translatus ab Johanne Hispano et Dominico Gundissalino. Edited by Clemens Baeumker. In Beiträge zur Geschichte der Philosophie des Mittelalters, Texte und Untersuchungen, vol. 1.2, edited by Clemens Baeumker and Georg von Hertling. 2nd ed. Münster: Aschendorff, 1995.

Ibn Gabirol, Solomon (Avicebron). The Font of Life (Fons Vitae). Translated by John A. Laumakis. Milwaukee: Marquette University Press, 2014.

Guttmann, Jacob. Die Philosophie des Salomon ibn Gabirol. Göttingen: Vandenhoeck \& Ruprecht's Verlag, 1889.

Guttmann, Jacob. Die Scholastik des dreizehnten Jahrhunderts in ihren Beziehungen zum Judenthum und zur jüdischen Literatur. Breslau: M. \& H. Marcus, 1902.

Guttmann, Julius. "Zu Gabirols allegorischer Deutung der Erzählung vom Paradies.” Monatsschrift für Geschichte und Wissenschaft des Judentums 80 (1936): 180-84. 
Halfwassen, Jens. "Ein Meister der Philosophie. Neue Literatur zu Meister Eckhart.” Philosophische Rundschau 58 (2011): 172-77.

Halfwassen, Jens. "Gibt es eine Philosophie der Subjektivität im Mittelalter? Zur Theorie des Intellekts bei Meister Eckhart und Dietrich von Freiberg." Theologie und Philosophie 72 (1997): 337-59.

Halfwassen, Jens. "Gott als Intellekt: Eckhart als Denker der Subjektivität." Meister-EckhartJahrbuch 5 (2011): 13-25.

Harvey, Warren Zev. "Filosofía y poesía en Ibn Gabirol." Anuario Filosófico 33, no. 67 (2000): 491504.

Israeli, Isaac. The Book of Definitions. In Isaac Israeli. A Neoplatonic Philosopher of the Early Tenth Century. Translation and commentary by Alexander Altmann and Salomon M. Stern. Chicago: University of Chicago Press, 2009.

Laumakis, John A. "Avicebron (Solomon ibn Gabirol) and Aquinas on Primary and Secondary Causality." PhD diss., Marquette University, 2001.

Kern, Udo. "Gottes Sein ist mein Leben." Philosophische Brocken bei Meister Eckhart. Berlin: De Gruyter, 2003.

Klein-Braslavy, Sara. "Bible Commentary." In The Cambridge Companion to Maimonides, edited by Kenneth Seeskin, 245-72. Cambridge: Cambridge University Press, 2005.

Klein-Braslavy, Sara. "The Philosophical Exegesis." In Hebrew Bible/Old Testament: The History of Its Interpretation, edited by Magne Sæbø, vol. 1, part 2: 302-20. Göttingen: Vandenhoeck \& Ruprecht, 2000.

Maimonides. The Guide of the Perplexed. Translated by Shlomo Pines. 2 vols. Chicago: University of Chicago Press, 1963.

McGinn, Bernard. "Ibn Gabirol: The Sage among the Schoolmen." In Neoplatonism and Jewish Thought, edited by Lenn E. Goodman, 77-109. Albany, NY: SUNY Press, 1992.

McGinn, Bernard. The Mystical Thought of Meister Eckhart: The Man from Whom God Hid Nothing. New York: Crossroad, 2001.

Mičaninová, Mária. "Was Aquinas Right When He Claimed That Avicebron Departed from Aristotle?" Archive of the History of Philosophy and Social Thought 62 (2017): 281-305.

Mojsisch, Burkhard. Meister Eckhart: Analogy, Univocity and Unity. Translated by Orrin F. Summerell. Amsterdam: B.R. Grüner, 2011.

Palazzo, Alessandro. "Eckhart's Islamic and Jewish Sources: Avicenna, Avicebron, and Averroes." In A Companion to Meister Eckhart, edited by Jeremiah M. Hackett, 253-98. Leiden: Brill, 2013.

Pessin, Sarah. Ibn Gabirol's Theology of Desire: Matter and Method in Jewish Medieval Neoplatonism. Cambridge: Cambridge University Press, 2013.

Pessin, Sarah. "Solomon Ibn Gabirol [Avicebron]." In The Stanford Encyclopedia of Philosophy, Winter 2016 Edition, edited by Edward N. Zalta: https://plato.stanford.edu/archives/win2016/ entries/ibn-gabirol/.

Polloni, Nicola. "Toledan Ontologies: Gundissalinus, Ibn Daud, and the Problems of Gabirolian Hylomorphism." In Appropriation, Interpretation and Criticism: Philosophical and Theological Exchanges Between the Arabic, Hebrew and Latin Intellectual Traditions, edited by Alexander Fidora and Nicola Polloni, 19-49. Barcelona: FIDEM, 2017.

Proclus. The Elements of Theology. Translated by Eric R. Dodds. 2nd ed. Oxford: Oxford University Press, 1971.

Pseudo-Aristotle. The Theology of Aristotle. Translated by Geoffrey Lewis. In Plotini Opera. Tomus II: Enneades IV-V. Edited by Hans-Rudolf Schwyzer and Paul Henry. Oxford: Oxford University Press, 1977.

Runia, David T. Philo in Early Christian Literature: A Survey. Assen: Van Gorcum; Minneapolis: Fortress Press, 1993. 
Schlanger, Jacques. The Philosophy of Solomon Ibn Gabirol. [Hebrew.] Jerusalem: Magnes Press, 1980.

Schwartz, Yossef. "Die Rezeption philosophischer Schriften aus dem Judentum." In Grundriss der Geschichte der Philosophie. Die Philosophie des Mittelalters IV: 13. Jahrhundert, edited by Peter Schulthess and Christoph Flüeler, 1:206-16. Basel: Schwabe Verlag 2017.

Schwartz, Yossef. "Meister Eckhart and Moses Maimonides: From Judaeo-Arabic Rationalism to Christian Mysticism." In A Companion to Meister Eckhart, edited by Jeremiah M. Hackett, 389-414. Leiden: Brill, 2013.

Schwartz, Yossef. "Salomon Ibn Gabirol: Zwischen Schöpfungsmythologie und Geheimnis der Einheit." In Platonismus im Orient und Okzident: Neuplatonische Denkstrukturen im Judentum, Christentum und Islam, edited by Raif G. Khoury, Jens Halfwassen, and Frederek Musall, 141-60. Heidelberg: Universitätsverlag Winter, 2005.

Schwartz, Yossef. "Thirteenth Century Hebrew Psychological Discussion: The Role of Latin Sources in the Formation of Hebrew Aristotelianism." In The Letter Before the Spirit: The Importance of Text Editions for the Study of the Reception of Aristotle, edited by Aafke M.I. van Oppenraay and Resianne Fontaine, 173-94. Leiden: Brill, 2012.

Schwartz, Yossef. "To Thee Is Silence Praise": Meister Eckhart's Reading in Maimonides' Guide of the Perplexed. [Hebrew.] Tel Aviv: Am Oved Publishers, 2002.

Spade, Paul V. "Binarium Famosissimum." In The Stanford Encyclopedia of Philosophy, Fall 2008 Edition, edited by Edward N. Zalta: https://plato.stanford.edu/archives/fall2008/entries/bina rium/.

Sterling, Gregory E. "Prepositional Metaphysics in Jewish Wisdom Speculation and Early Christological Hymns." Studia Philonica Annual 9 (1997): 219-38.

Vinco, Roberto. "Meister Eckhart's Non-standard Natural Theology." Neue Zeitschrift für Systematische Theologie und Religionsphilosophie 58, no. 4 (2016): 473-88.

Weisheipl, James A. "Albertus Magnus and Universal Hylomorphism: Avicebron. A Note on Thirteenth-Century Augustinianism." In Albert the Great: Commemorative Essays, edited by Francis J. Kovach and Robert W. Shahan, 239-60. Norman: University of Oklahoma Press, 1980.

Wittmann, Michael. Die Stellung des hl. Thomas von Aquin zu Avencebrol (Ibn Gebirol) im Entwicklungsgang der arabischen Philosophie. In Beiträge zur Geschichte der Philosophie des Mittelalters, Texte und Untersuchungen, vol. 3.3, edited by Clemens Baeumker and Georg von Hertling. Münster: Aschendorff, 1900. 
